7

\title{
High-resolution landform assemblage along a buried glacio-erosive surface in the SW Barents Sea revealed by P-Cable 3D seismic data
}

Benjamin Bellwald ${ }^{\mathrm{a}}$, Sverre Planke ${ }^{\mathrm{a}, \mathrm{b}, \mathrm{c}}$, Nina Lebedeva-Ivanova ${ }^{\mathrm{a}}$, Emilia D. Piasecka $^{\mathrm{d}}$, Karin Andreassen $^{\mathrm{d}}$

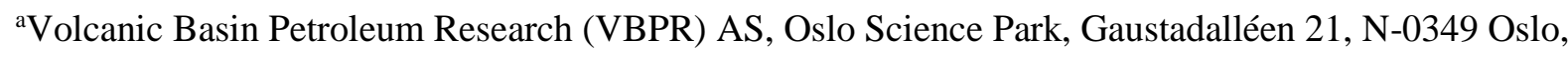
Norway

${ }^{\mathrm{b} C e n t r e ~ f o r ~ E a r t h ~ E v o l u t i o n ~ a n d ~ D y n a m i c s ~(C E E D), ~ U n i v e r s i t y ~ o f ~ O s l o, ~ S e m ~ S æ l a n d s ~ v e i ~ 1, ~ N-0371 ~}$ Oslo, Norway

${ }^{\mathrm{c}}$ Research Centre for Arctic Petroleum Exploration (ARCEx), UiT The Arctic University of Norway, N-9037 Tromsø, Norway

${ }^{\mathrm{d} C e n t r e}$ for Arctic Gas Hydrate, Environment and Climate (CAGE), UiT The Arctic University of Norway, N-9037 Tromsø, Norway

Corresponding author. E-mail address: benjamin@vbpr.no (B. Bellwald) 
The Quaternary sedimentary record in the Arctic captures a diverse and evolving range of landscapes reflecting climate changes. Here we study the geological landform assemblage of the Upper Regional Unconformity (URU) in the SW Barents Sea. The aims are (i) to characterize buried geological landforms on a meter-scale resolution, ii) to understand their link with underlying structures, and (iii) to reconstruct paleo-ice-sheet dynamics and configurations. The data consist of a high-resolution three-dimensional (3D) P-Cable seismic cube with an extent of c. $200 \mathrm{~km}^{2}$ and an inline separation of $6 \mathrm{~m}$. Dominant frequencies of c. $150 \mathrm{~Hz}$ allow to image landforms at URU with a vertical resolution of 1-5 $\mathrm{m}$ and a horizontal resolution of 3$6 \mathrm{~m}$. We conduct detailed horizon-picking and seismic attribute analysis of the buried URU horizon. We identified four sets of mega-scale glacial lineations, and shear band ridges located to the west of a shear margin moraine. Other characteristic features include hill-hole pairs, transverse ridges, rhombohedral ridges and depressions, iceberg ploughmarks and pockmarks. Polygonal faults below URU and deeper faults have a strong effect on the location of structures observed on URU. Bedrock packages deformed down to $30 \mathrm{~m}$ below URU and up to $5 \mathrm{~m}$-high transverse ridges at URU are imprints of glacio-tectonic activity. Deformed strata below URU indicate normal faulting superimposed by glaciotectonic deformation. The four sets of megascale glacial lineations indicate four streaming events with thawed glacial beds, with shear band ridges forming in the shearing zone during one of these streaming events. Hill-hole pairs and rhombohedral ridges are frozen-bed features which indicate a polythermal regime at the base of the Barents Sea Ice Sheet during multiple streaming phases. This study therefore shows that paleo-ice streams have been temporarily frozen to the ground in the SW Barents Sea, and that landforms evidencing this freezing are associated with underlying faults.

Keywords: Upper Regional Unconformity, Barents Sea, Thermokarst, Hill-hole pair, Glacial shearing, Seismic geomorphology 
High-latitude continental shelves have been intensively eroded during Pleistocene glaciations (Laberg et al., 2012). Ice streams transported large amounts of sediments from these shelves to the continental slopes (Nygård et al., 2007). Most of the eroded sediments are deposited in trough mouths fans, which are glaciated depocenters comprising several $1000 \mathrm{~km}^{3}$ of sediments (Vorren and Laberg, 1997; Nygård et al., 2005; Hjelstuen et al., 2007). Buried paleo-seabed surfaces corresponding to prominent erosional unconformities include a large variety of geological landforms and are valuable records of past glaciations (Bentley and Anderson, 1998; Dowdeswell and Ottesen, 2013). Landforms identified along glacial surfaces indicate changes in ice-stream dynamics and variable thermal regimes at the bottom of an ice stream (Rise et al., 2004; Winsborrow et al., 2016). Mega-scale glacial lineations evidence warmbase ice streams, whereas hill-hole pairs are typical subglacial landforms in cold-base ice regimes (Clark et al., 2003; Andreassen and Winsborrow, 2009; Bøe et al., 2016). Iceberg ploughmarks commonly express episodes of ice disintegration (Dowdeswell et al., 2008; López-Martínez et al., 2011), which are followed by fluid escape events evidenced by pockmarks (Mazzini et al., 2017; Tasianas et al., 2018).

Thermokarst develops as a consequence of thawing permafrost as a response to climate warming (Hassol, 2004). Thermokarst geomorphologies, documented in periglacial regions of the Earth and Mars (e.g., Kvenvolden, 1988; Costard and Kargel, 1995), indicate the presence of ice-rich sedimentary deposits in the subsurface. Gas hydrates are ice-like deposits found underneath the oceans (Maslin et al., 2010; Serov et al., 2017), and below permafrost on shallow Arctic continental shelves and land areas (Kvenvolden, 1988). Thermokarst has played an important role in shaping permafrost landscapes (French, 2007; Murton, 2009), and thawing permafrost is known to emit methane and to have global environmental implications (Zimov et al., 1997). Landforms indicative of thermokarst include detachment slides, thaw slumps, thermal erosion gullies, as well as thermokarst lakes, pits and troughs (Kokelj and Jorgenson, 2013).

Glaciated petroleum provinces are preconditioned to sequester large fluxes of methane subglacially (Andreassen et al., 2017). Gas hydrates below the seabed have been proposed to act as sticky spots at the base of the Barents Sea Ice Sheet, and consequently affect the flow dynamics of ice streams 
(Winsborrow et al., 2016) (Fig. 1a). Freeze-on processes at the base of ice streams favorably occur in ice stream shearing zones (Bøe et al., 2016), but could also be a common behavior of marine ice streams (Andreassen and Winsborrow, 2009). Subglacial shearing is documented by structures in outcrops, microstructural analysis of glacial tills, and interpretation of seismic geomorphologies (Phillips et al., 2011; Bellwald et al., 2018a).

The decay and growth of the North Atlantics major ice sheets is documented by ice cores as well as marine and terrestrial records (Hughes et al., 2016). The characteristics and distribution of glacial landforms that develop at the margin and beneath a glacier reflect prevailing climate and glacier-bed conditions at the time of formation (Clayton and Moran, 1974; Attig et al., 1989; Kleman and Borgström, 1996; Stroeven et al., 2016). Knowledge about thermokarst, gas hydrates and shallow gas is relevant for slope stability assessments, ecosystem analysis, carbon cycling and greenhouse gas budgets (Walter et al., 2007; Schuur et al., 2008; Sannel and Kuhry, 2011). Gas is inferred to migrate from the shallow subsurface to the seabed, and kilometer-wide craters and mounds at the seabed of the central Barents Sea are associated with large-scale methane expulsions (Andreassen et al., 2017) (Fig. 1a). Detailed knowledge about glacial unconformities and related geological landforms in the subsurface is demanded by offshore industries to assess drilling hazards and guarantee infrastructure stability (Huuse et al., 2012; Bellwald and Planke, 2018). Ignoring small-scale subsurface expressions, for example, may have severe costly consequences like shearing of well-casing due to fault reactivation or sinkholes at a later stage (Otto, 2018). The Barents Sea Ice Sheet further offers a good geological analogue to the contemporary West Antarctic Ice Sheet. Landforms related to ice shearing allow conclusions about past ice-stream regimes and comparisons with ongoing climate change.

Geophysical data are powerful tools to characterize the geomorphology of glacial surfaces (Rise et al., 2004; Montelli et al., 2017). Acoustic methods based on marine echo-sounding principles are currently the most widely used techniques for mapping submarine glacial landforms (Jakobsson et al., 2016). New 3D seismic technologies allow mapping of buried horizons in a resolution similar to the seabed (Bellwald et al., 2018a), and the data can thus be used as hints for the glacial development of the area. Three-dimensional seismic data has given birth to the discipline of seismic geomorphology, and allow 
to characterize paleo-seabed features (Posamentier et al., 2007). Streamlined grooves with lengths of tens of kilometers have been mapped along Upper Regional Unconformity (URU), a buried paleoseabed, in conventional seismic data covering $\sim 13,000 \mathrm{~km}^{2}$ of the region (Piasecka et al., 2016) (Fig. 1b). Glacial landforms and fluid-related structures with dimensions less than $10 \mathrm{~m}$ have been identified along glacial (paleo)surfaces in high-resolution P-Cable 3D seismic data of the Barents Sea (Bellwald et al., 2018; Tasianas et al., 2018). These studies showed that high-resolution 3D landform characterization results in a better geological understanding, and that glacial landforms could provide Pleistocene analogues to present-day processes and climate changes (Andreassen et al., 2017). Here we map a variety of meter-scale glacial landforms and bedrock structures at URU, which are not resolvable in conventional seismic data. We interpret a $\sim 200 \mathrm{~km}^{2}$ high-resolution P-Cable 3D seismic cube of the Hoop Fault Complex area in the SW Barents Sea (Fig. 1b), and aim to improve the understanding of the processes active at a paleo-seabed surface. Small subglacial landforms identified in this study provide information about the thermal regime of the former Barents Sea Ice Sheet, the occurrence of shallow gas and gas hydrates, and have thus implications for both offshore investigations and ice-sheet reconstructions.

\section{Study area}

The SW Barents Sea shelf experienced high erosion rates by repeated glaciations during the Pleistocene (Laberg et al., 2012). These erosive episodes shaped URU (Sættem et al., 1992), which divides Lower Cretaceous/Jurassic seaward-dipping stratified sedimentary rocks from sub-parallel layered unlithified Quaternary sediments in the Barents Sea (Solheim and Kristoffersen, 1984; Vorren et al., 1986; Solheim et al., 1996). The bedrock formation directly underlying URU in the study area is the Kolmule Formation, which is dated to the Aptian/middle Cenomanian time period (www.npd.no). The Kolmule Formation is considered to be dominated by mudstones with thin siltstones, limestone interbeds and dolomite stringers deposited in an open marine environment (www.npd.no). Glacio-erosive processes at the base of the former Barents Sea Ice Streams transported sediments from the continental shelf to the Bear Island Trough Mouth Fan, which comprises a volume of c. $670,000 \mathrm{~km}^{3}$ and is location of large slides (Vorren et al., 1991; Laberg and Vorren, 1995; Hjelstuen et al., 2007). The large sediment volume 
of the Bear Island Trough Mouth Fan implies considerable erosion of the source region, but the timing and mechanisms of this erosion are not yet well understood (Ktenas et al., in press). The pre-Quaternary relief of the SW Barents Sea has been estimated to several hundreds of meters above sea level (Dimakis et al., 1998; Butt et al., 2002).

During the Last Glacial Maximum (LGM), the Eurasian ice sheet complex as a whole attained its maximum extent and volume at c. $21 \mathrm{ka}$ (Hughes et al., 2016). However, details on the changing extent of the Eurasian ice sheet complex are poorly documented in the Barents Sea compared to the coastlines of Svalbard and Scandinavia (Hughes et al., 2016). The study area was ice-covered from c. 24 ka until c. $16 \mathrm{ka}$, whereas there is not a lot known about the spatial extent of the Barents Sea glaciation pre-25 ka. According to few existing radiocarbon dates, the last major deglaciation started at c. $16.9 \mathrm{ka}$, and was followed by stepwise retreat from the SW Barents Sea to a location east of Svalbard by c. 11.3-12 ka (Salvigsen, 1981; Rüther et al., 2011, 2017). This ice sheet retreat was highly asynchronous, with the most rapid retreat experienced across the Barents Sea sector after 17.8 ka when this marine-based ice sheet disintegrated at a rate of c. 670 gigatonnes per year and with surface velocities of c. $400 \mathrm{~m} / \mathrm{a}$ (Patton et al., 2017).

The use of crustal rebound information to construct the Eurasian ice-sheet dimensions has been widely used for the LGM and post-LGM periods (Boulton et al., 2001; Siegert et al., 2001). Glacial rebound modeling is well established for the post-LGM period in Scandinavia, as the observational evidence is relatively abundant and well distributed spatially and in time (Lambeck et al., 2010). For the pre-LGM time periods, however, evidence becomes increasingly sparse and uncertain (Arnold et al., 2002; Lambeck et al., 2010). Fjeldskaar and Amantov (2018) modeled an isostatic response of $800 \mathrm{~m}$ for the last million years in the Barents Sea. The estimated amount of glacial erosion during the Quaternary varies by several magnitudes, from tens of meters in the central Barents Sea to $1000 \mathrm{~m}$ close to the shelf break (Fjeldskaar and Amantov, 2018).

The SW Barents Sea is location of several oil and gas discoveries, including Snøhvit and Goliat close to the mainland and Wisting in the Hoop Fault Complex area (Fig. 1a) (www.npd.no). This study focuses on the Hoop Fault Complex area, which is located in an overdeepened cross shelf trough, named 

1b).

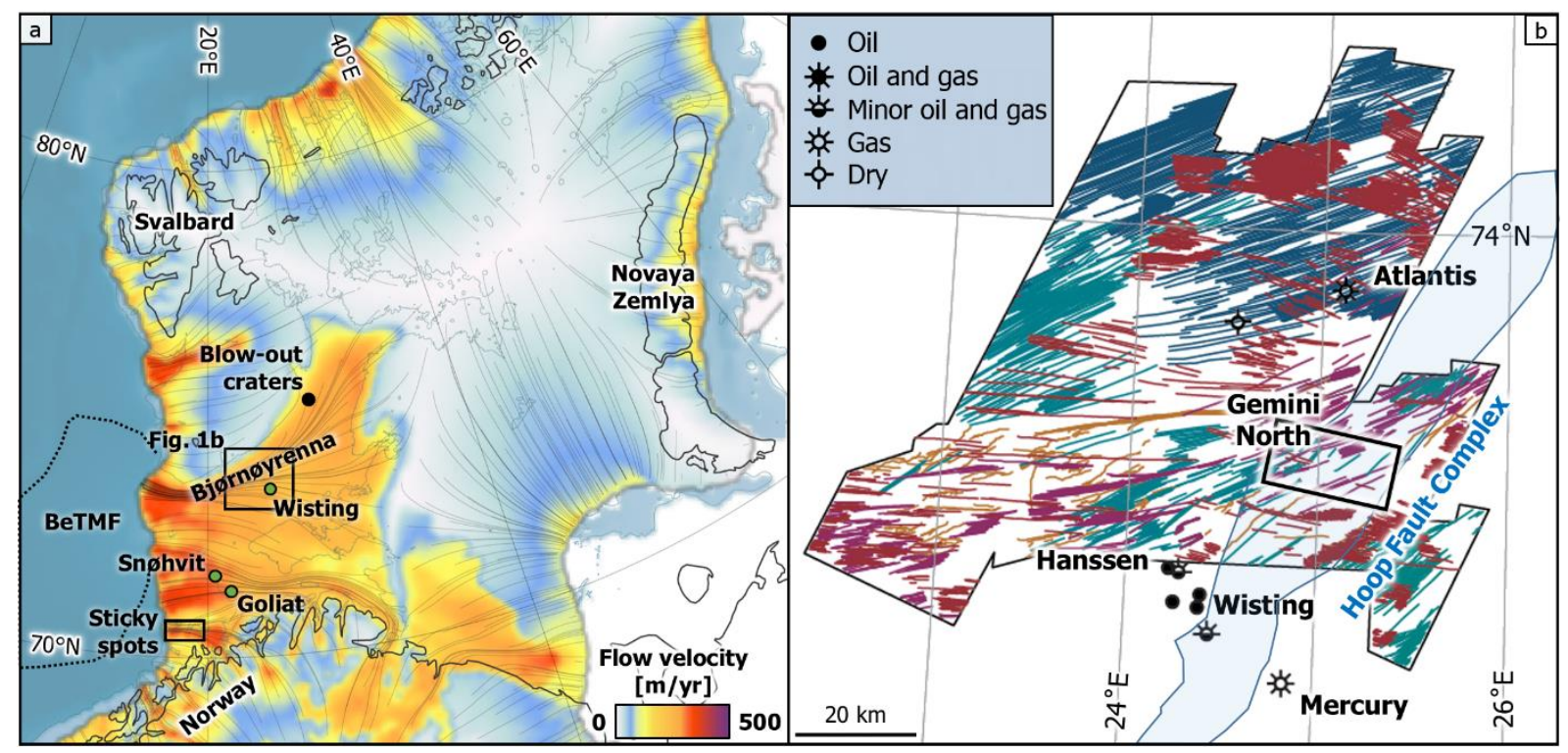

Fig. 1. Study area. a) Western Barents Sea Ice Sheet with ice-flow vectors at Last Glacial Maximum

(Patton et al., 2016), petroleum discoveries (green dots, www.npd.no), location of sticky spots

(Winsborrow et al., 2016), and large pockmarks (blow-out craters, Andreassen et al., 2017). BeTMF:

Bear Island Trough Mouth Fan. b) Sets of mega-scale glacial lineations and ploughmarks mapped out in conventional 3D seismic data of the Hoop Fault Complex area (Piasecka et al., 2016) (lineations indicated by different colors), location of high-resolution P-Cable 3D seismic cube (black box), and petroleum wells (www.npd.no).

\section{Data and methods}

Seismic data are acquired by different technologies and setups, and high-resolution imaging of the shallow subsurface is strongly dependent on the system configurations (Lebedeva-Ivanova et al., 2018). The strength of high-resolution P-Cable 3D seismic data is to image meter-scale glacial landforms, which are not resolved by conventional 3D seismic data (Bellwald and Planke, 2018). Therefore these technologies are discussed in detail in the following section. 


\begin{tabular}{|c|c|c|}
\hline \multicolumn{3}{|l|}{ Streamers } \\
\hline Number of streamers & 16 & 8 \\
\hline Streamer length [m] & 25 & 6000 \\
\hline Streamer separation $[\mathrm{m}]$ & 12.5 & 100 \\
\hline Streamer tow depth $[\mathrm{m}]$ & 2.5 & $8-12$ \\
\hline \multicolumn{3}{|l|}{ Source } \\
\hline Volume [in $\left.{ }^{3}\right]$ & 300 & 3400 \\
\hline Source tow depth $[\mathrm{m}]$ & 2.5 & 6 \\
\hline \multicolumn{3}{|l|}{ Source spectrum } \\
\hline Dominant $[\mathrm{Hz}]$ & 120 & $50-70$ \\
\hline Maximum [Hz] & c. 300 & c. 100 \\
\hline Shot point interval $[\mathrm{m}]$ & 12.5 & 18.75 \\
\hline Bin size $[\mathrm{m}]$ & $6.25 \times 4.75$ & $6.25 / 12.5 \times 18.75 / 25$ \\
\hline Fold for conventional bin size & 16 & $8-12$ \\
\hline
\end{tabular}

Parameter

Conventional 3D seismic data of the Hoop Fault Complex area have been collected using a dual-source $3400 \mathrm{in}^{3}$ airgun and a streamer spread of $8 \times 100 \mathrm{~m} \times 6000 \mathrm{~m}$. Conventional 3D seismic data cover an area of c. $13,000 \mathrm{~km}^{2}$ in the Hoop Fault Complex area (Fig. 1b), with typical bin sizes of $6.25 / 12.5 \times 18.75 / 25 \mathrm{~m}$. The P-Cable data of this study were acquired using a $300 \mathrm{in}^{3}$ airgun source and 16 streamers separated by $12.5 \mathrm{~m}$ and a length of $25 \mathrm{~m}$, and a sailing line distance of $70 \mathrm{~m}$. The P-Cable data cover an area of c. $200 \mathrm{~km}^{2}(21 \times 11 \mathrm{~km})$, and have a bin size of $6.25 \times 4.75 \mathrm{~m}$, and short offsets of 120-165 m. With short offsets between source and receiver, the P-Cable 3D data provide higher frequencies than conventional 3D seismic systems. The acquisition parameters of these two technologies are listed in Table 1.

Table 1. Typical settings of 3D seismic data in the SW Barents Sea. Frequencies have been calculated for a water depth of $450 \mathrm{~m}$, an URU depth of $50 \mathrm{~m}$ below seabed and a P-wave velocity of $1700 \mathrm{~m} / \mathrm{s}$ for glacial sediments. The seismic data were provided by TGS, VBPR and WGP.

P-Cable 3D

Conventional 3D 
181 for $-20 \mathrm{~dB}$ of minimal reliable amplitude of the seismic signal at URU depths (Fig. 2). The frequency

182 bandwidths of the raw data can be increased by later processing of the seismic data. TGS and DECO

183 processed the P-Cable seismic data, and thereby increased the frequency and resolution of the shallow subsurface (Fig. 2). Processed P-Cable data have a bandwidth of up to $350 \mathrm{~Hz}$ in the shallow subsurface.

185 For an average URU depth of $50 \mathrm{~m}$ bsf, the processed P-Cable data have a dominant frequency of c. 120

$186 \mathrm{~Hz}$ and a maximum frequency of c. 280-320 Hz (Tab. 1, Fig. 2). Conventional 3D seismic data of the

187 same area are characterized by dominant frequencies of $50-70 \mathrm{~Hz}$ and maximum frequencies of $100 \mathrm{~Hz}$

188 (Tab. 1).

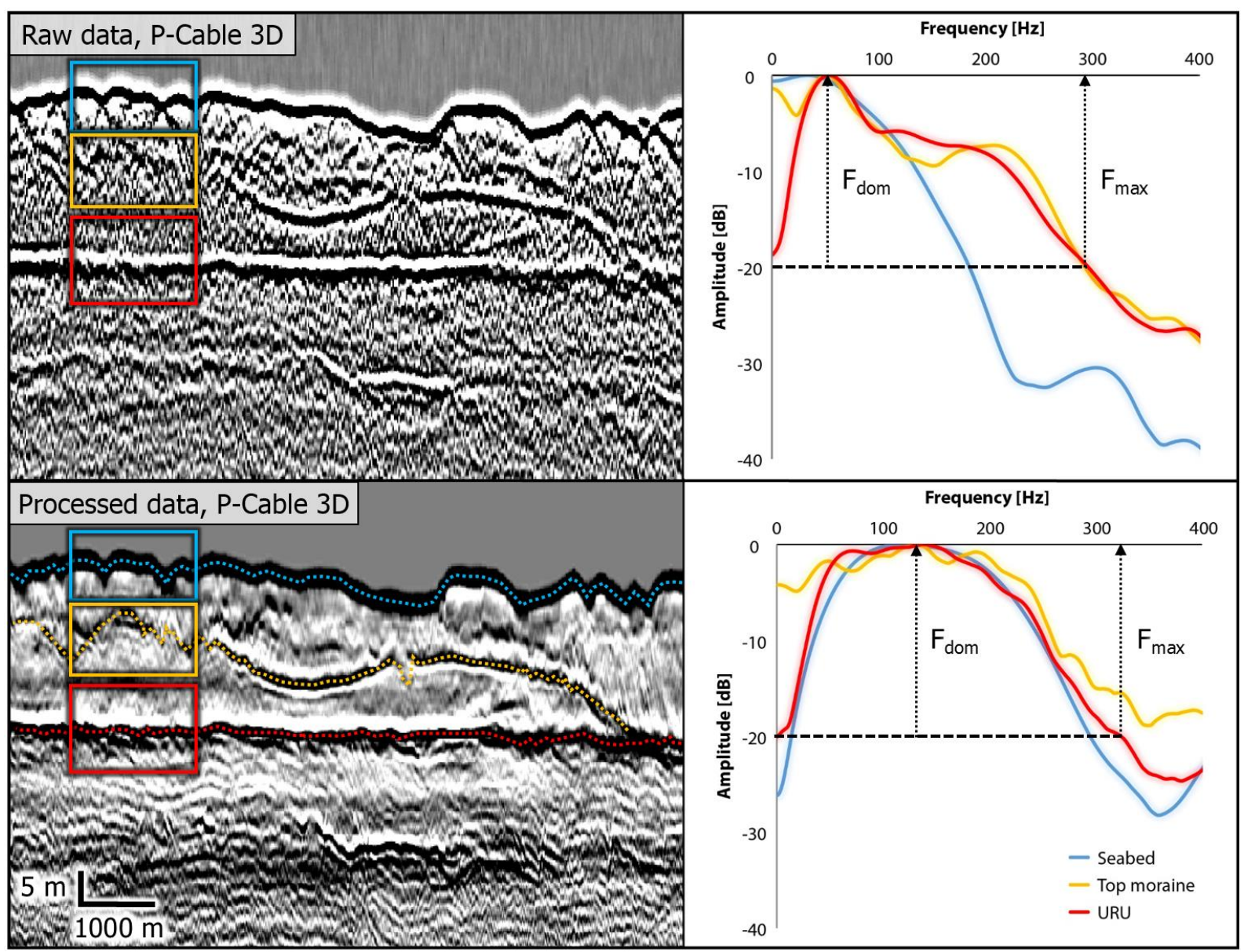

190 Fig. 2. Single channel raw (upper panel) and processed (lower panel) P-Cable 3D seismic data, and

191 frequency bandwidths on the right for both datasets, respectively. The data example is from the Hoop

192 Fault Complex area. Top moraine is a reflection within the glacial package described in Bellwald and

193 Planke (2018) and Bellwald et al. (2018a). $F_{\text {dom: }}$ Dominant frequency, $F_{\max }$ : Maximum frequency. 
194 Resolution means the minimum distance by which two features must be separated as distinct entities 195 (Sheriff, 1999), and is often defined by the Rayleigh resolution limit as quarter of a wavelength $(\lambda / 4$; 196 Kallweit and Wood, 1982). The wavelengths for prominent glacial reflections of the studied data are 197 displayed in a wiggle-trace profile of processed seismic data in Fig. 3a. Using quarter of a wavelength 198 as the resolution limit, structures as small as $1.5-3.5 \mathrm{~m}$ can be vertically resolved in P-Cable data at URU 199 depths. Such a high resolution at URU depths is supported by increased values in the instantaneous 200 frequency plot (Fig. 3b).

201 Resolution can also be defined when dividing the P-wave velocity by the frequency. Using the 202 instantaneous frequency (Fig. 3b), structures can vertically be resolved by c. $5 \mathrm{~m}$ at seabed (70 Hz) and 203 by c. $3 \mathrm{~m}$ at URU $(120 \mathrm{~Hz})$. The improvements in resolution in the shallow subsurface compared to the seabed are caused by the migration of the seismic data. These estimates are consistent with the results obtained using the quarter-of-a-wavelength criteria. The rough and hard seabed of the SW Barents Sea (e.g., Gudlaugsson et al., 2013) could be another reason for lower frequencies at the seabed compared to the shallow subsurface (Figs. 2, 3), as the high-frequency signal might be scattered at this horizon. The vertical resolution used in the following has been calculated by quarter of a wave length, and the horizontal resolution of migrated seismic data is twice the vertical resolution. Seismic profiles show that features along, atop and below URU can be imaged in much more detail using high-resolution P-Cable 3D seismic data compared to conventional 3D (Fig. 4). 


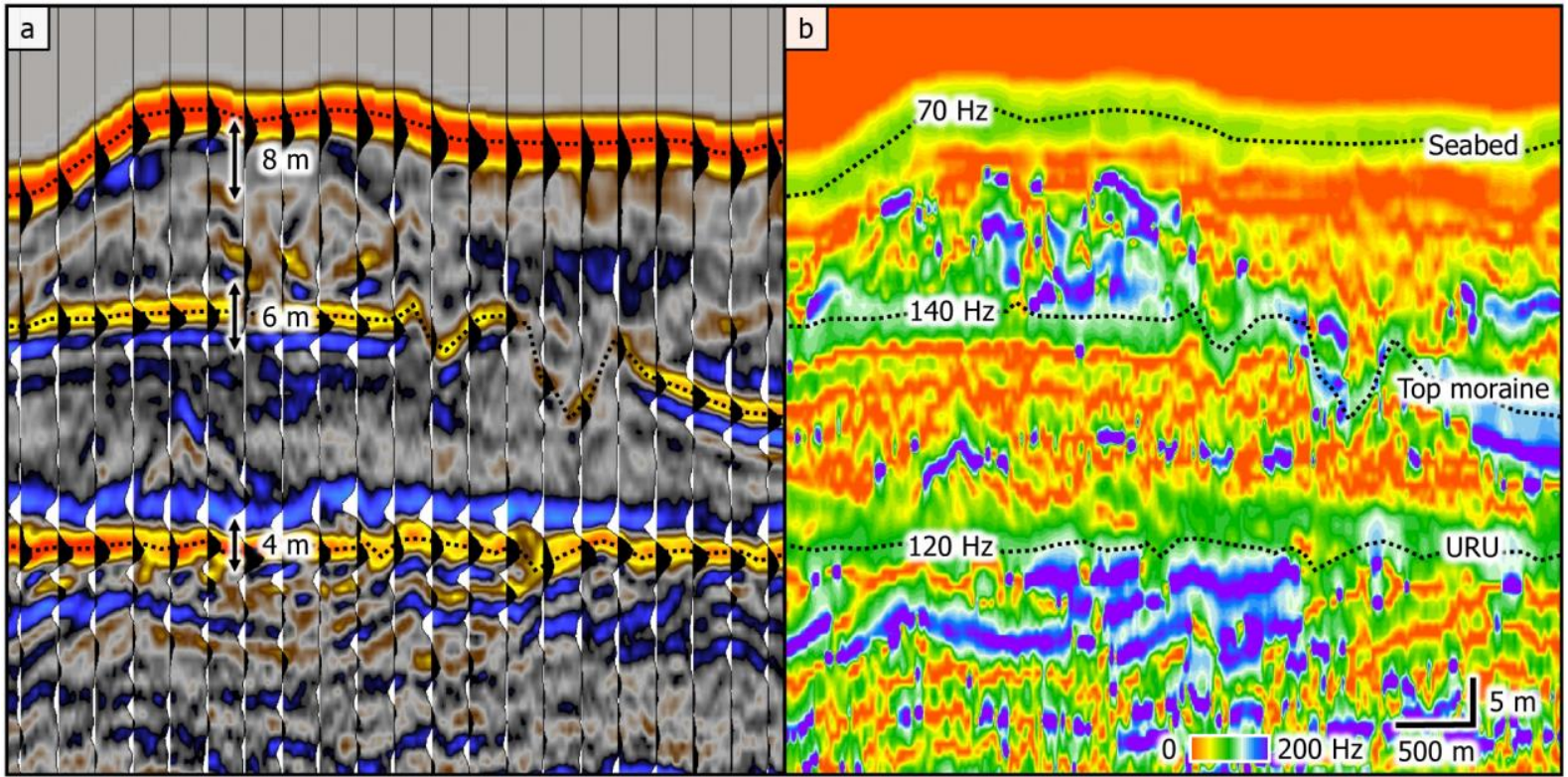

213 Fig. 3. Vertical resolution on processed P-Cable 3D seismic data at different glacial surfaces. a) Wiggletrace profiles. The wavelengths at different levels are determined by measuring the time between two troughs or peaks of a wiggle-trace profile as shown by arrows in the plot. The vertical resolution can be defined as quarter of a wavelength. Features along the seabed can be resolved in c. $2 \mathrm{~m}$, whereas URU structures can be resolved in up to $1 \mathrm{~m}$. b) Instantaneous frequency of vertical resolution. The vertical resolution, calculated by the division of P-wave velocity $(1700 \mathrm{~m} / \mathrm{s})$ by instantaneous frequency, is estimated to c. $5 \mathrm{~m}$ for the seabed and c. $3 \mathrm{~m}$ at URU depths. Main seismic horizons are indicated by black stippled lines.

The interpretation of the seismic data has been done in Kingdom V.2015 based on the concept of seismic geomorphology (Posamentier et al., 2007). The URU reflection of the Hoop Fault Complex area is defined as the positive amplitude reflection separating semi-continuously deposited glacial sediments from westward-dipping bedrock of Lower Cretaceous age (Fig. 4). URU has been picked in depths of 640-680 ms for every $10^{\text {th }}$ inline (62.5 $\mathrm{m}$ spacing) throughout the P-Cable cube and up to every second inline (12.5 m spacing) in selected areas. URU is often overlain a negative-amplitude reflection (Figs. $4 \mathrm{c}, \mathrm{d})$, which is called soft reflection in the following.

The structure maps are generated by snapping an interpolated grid to the maximum amplitude reflection of a vertical window of $5 \mathrm{~ms}$. Time has been converted to depth using a velocity of $1500 \mathrm{~m} / \mathrm{s}$ for water 

geological expressions (Fig. 5c).

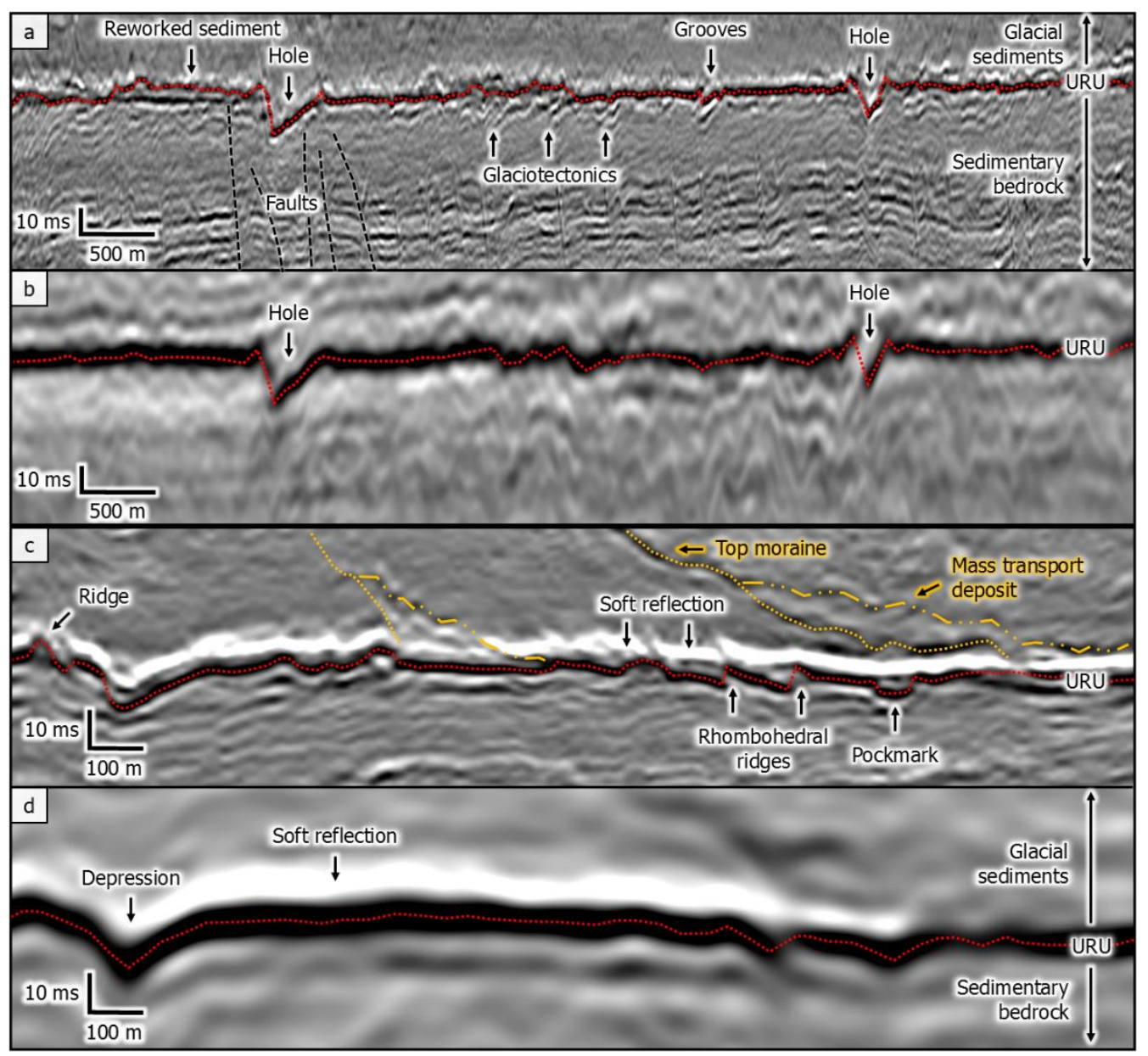

Fig. 4. Comparison of vertical resolution of the URU reflection. a) P-Cable 3D seismic profile across an area dominated by active ice-streaming. Glacial landform assemblage indicates changing thermal regimes. Mound of hill-hole pair, glaciotectonically deformed strata and shallow faults are visible. b)

237 Conventional 3D seismic profile across the area dominated by active ice-streaming. Only main 238 structures can be imaged. c) P-Cable 3D seismic profile across an area dominated by thermokarst.

239 Rhombohedral ridges and pockmarks are clearly distinguishable landforms, and soft reflection shows

240 lateral variability. The glacial sediment package atop URU includes a shear margin moraine and mass

241 transport deposits. d) Conventional 3D seismic profile across the area dominated by thermokarst.

242 Structures along URU cannot be imaged in high resolution. The soft reflection is more continuous.

243 Seismic data by TGS, WGP and VBPR. 


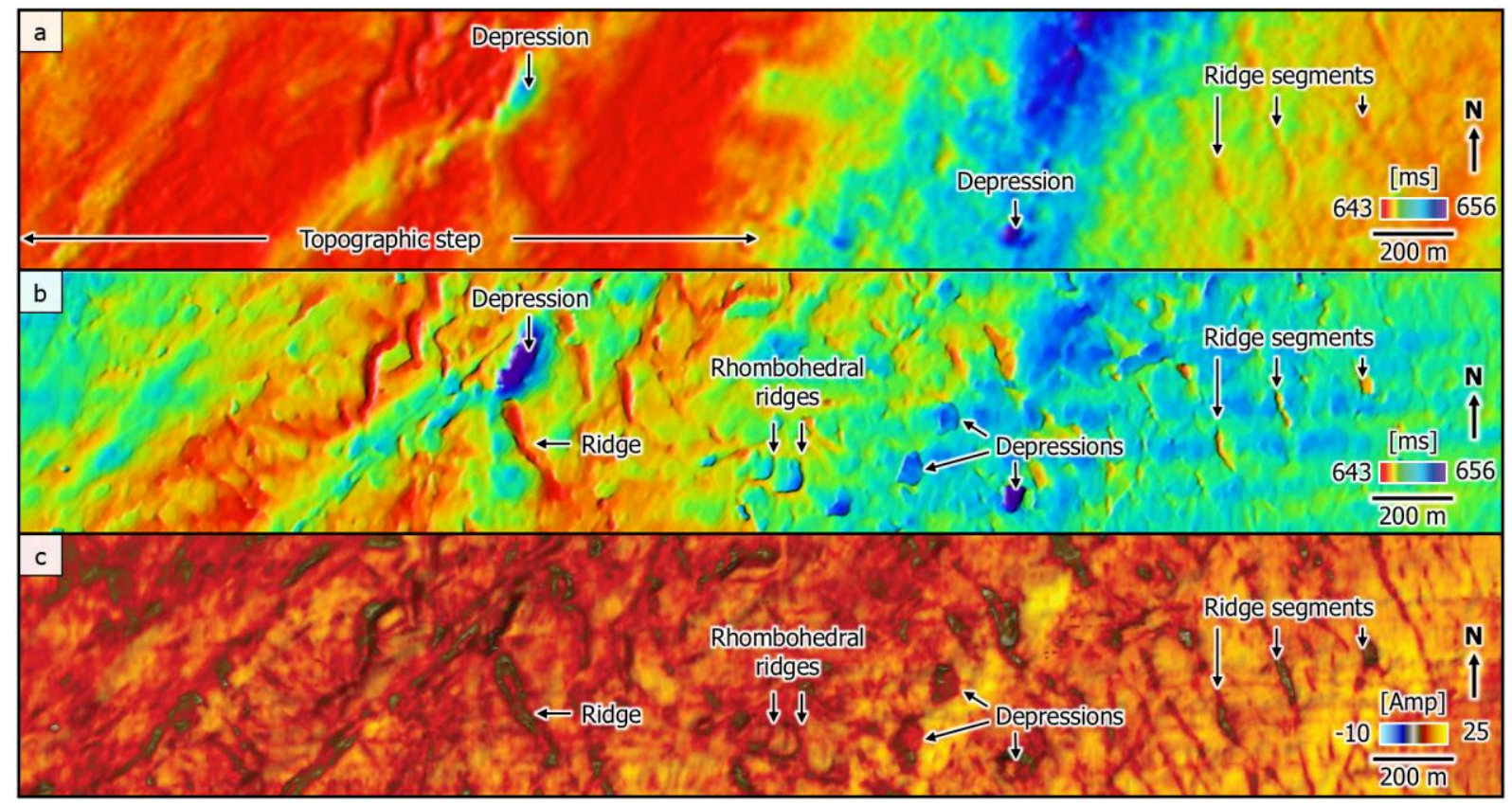

245 Fig. 5. Comparison of imaging quality of URU by commonly used 3D seismic technologies over the same area. a) URU structure map based on conventional 3D seismic data with a bin size of $12.5 \times 18.75$ m. b) URU structure map based on P-Cable 3D seismic data with a bin size of $6.25 \times 4.75 \mathrm{~m}$. c) Peak seismic amplitude of interpreted URU reflection of the P-Cable 3D seismic data.

\section{Geomorphology of glacial landforms}

The following section describes the seismic geomorphology of small-scale URU features. It discusses the imaging possibilities by high-resolution P-Cable 3D seismic data and geological processes involved in the formation of these geomorphologies. As any form of image interpretation has its natural limits due to lacking opportunities for ground checks or other methods that could be applied at terrestrial study sites, we compare the URU landforms with morphologies from terrestrial archives for the interpretation of the individual landforms.

\subsection{Large structures}

Description: The main URU structures include several southeast-northwest trending channels along a 1200-2300 $\mathrm{m}$ wide depression in the northeastern part of the cube (Fig. 6). A $3 \mathrm{~m}$ high and 2000-2500 m wide northeast-southwest-oriented topographic step shapes URU southeast of the study area. The 
terrains at and southeast of the topographic step are dominated by trough-transverse, linear ridge

segments, rhombohedral networks of ridges, and circular to oval-shaped depressions. Both the topographic step and the major depression are also imaged in conventional 3D seismic data (Fig. 5).

Interpretation: The channels along the major depression have previously been interpreted as a proglacial braided channel system, which was named Bjørnelva and formed in a time period when the Barents Sea Ice Sheet was melting (Bellwald et al., in review). Rhombohedral landforms and rimless circular to ovalshaped lakes on Mars, in Canada and Siberia are documented to form related to thermokarst (e.g., Soare et al., 2008; Morgenstern et al., 2011; Grosse et al., 2013; Lobkovsky et al., 2016). Following these interpretations, we suggest the rhombohedral, circular and oval-shaped expressions characterizing the topographic high to represent a landscape generated by thermokarstic processes. The individual landforms are described and interpreted in section 4.2

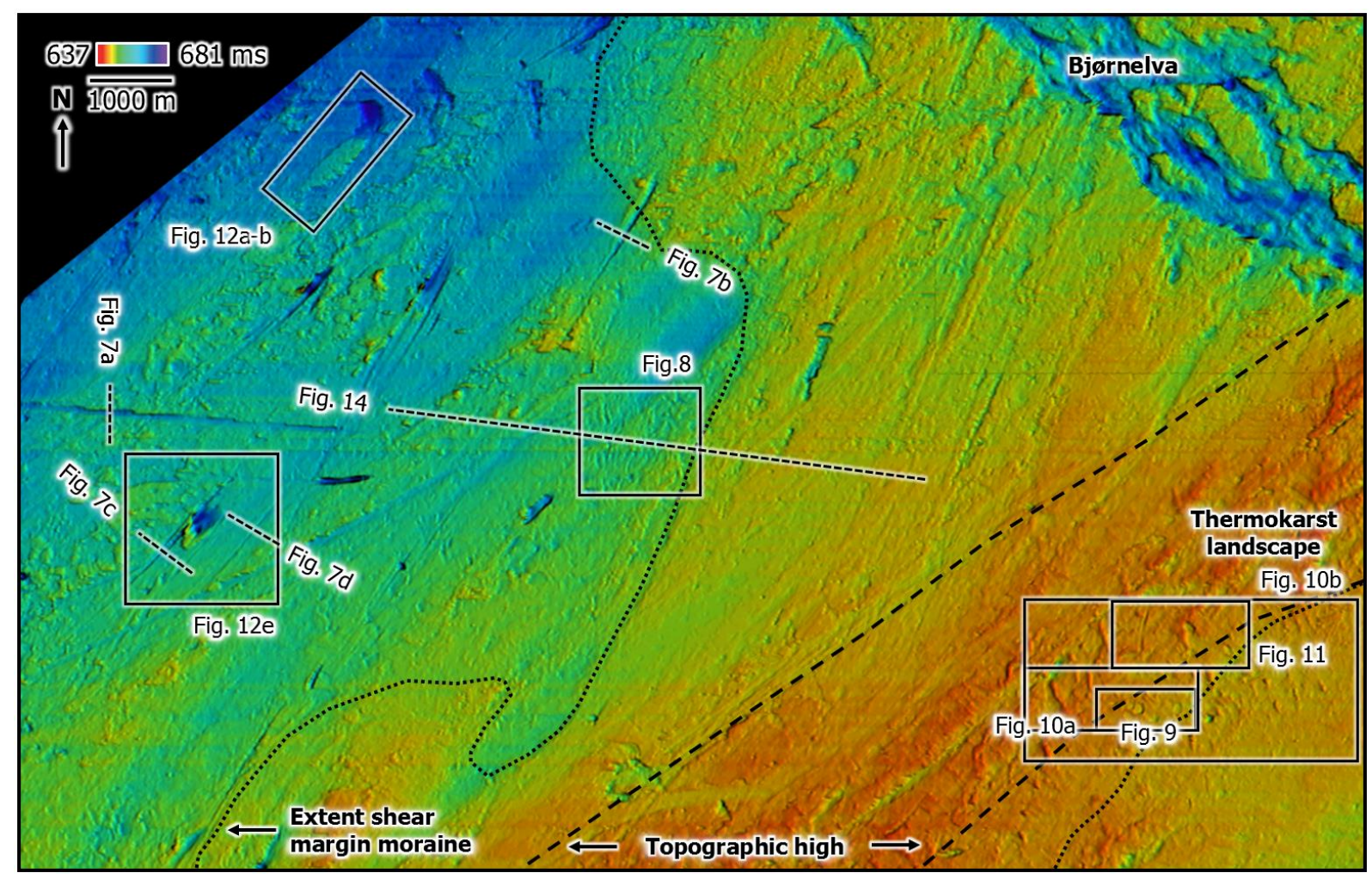

Fig. 6. URU structure map generated using P-Cable 3D seismic data. Extent shear margin moraine from Bellwald and Planke (2018). 
Description: Elongated V-shaped grooves with lengths of 1-5 km occur all over the study area, and can be categorized in four sets with orientations varying from NNE-SSW to E-W. Having widths of 20-200 $\mathrm{m}$, the grooves have an average length:width ratio of 25:1.A first type of grooves is 100-200 m wide and 5-10 $\mathrm{m}$ deep with up to $4 \mathrm{~m}$ high rims (Figs. 7a, b). A second type of grooves is 20-100 $\mathrm{m}$ wide and 1-5 m deep, and is only occasionally associated with rims (Figs. 7c, d). The second type of grooves is often characterized by multiple depressions (Fig. 7c). There is no correlation between groove depth and groove orientation. A total of 103 grooves has been identified in the study area, with 2 grooves associated to set 1,35 associated to set 2, 52 associated to set 3 , and 14 associated to set 4 . The reflections below the grooves are bended and inclined (Fig. 7).

Interpretation: Linear, wide and shallow ridge-groove features are interpreted as mega-scale glacial lineations (MSGL; Andreassen et al., 2004; Ó Cofaigh et al., 2005; Shaw et al., 2006; Jakobsson et al., 2011). The identified lineation lengths of 1-5 km of our study correlate with MSGLs identified in large terrestrial datasets with lengths of 1-2 km (Spagnolo et al., 2014). Lineation widths of 20-200 m fit with the mean width of $>17,000$ lineations from the central trunk of Dubawnt Lake paleo-ice stream bed (Stokes et al., 2013), whereas the lineations of our study are characterized by an increased elongation ratio. We suggest the first type of elongated grooves along URU to represent glacial lineations, indicating four ice-stream flow directions along URU. The rims are most likely the result of subglacial sediment deformation, as suggested by Tulaczyk et al. (2001) (Fig. 7a). Elongated landforms that are narrower than mega-scale glacial lineations have been interpreted as glacial flutes based on statistical analysis using a global database (Ely et al., 2016). Glacial flutes with similar dimensions as this second flute-type of grooves are documented in the Weedsport drumlin field, New York State, USA (Gentoso et al., 2011). However, even if MSGL generally include both grooves and ridges, they could also only consist of a groove (Spagnolo et al., 2014). Thus, we interpret this second type of narrower and shallower 


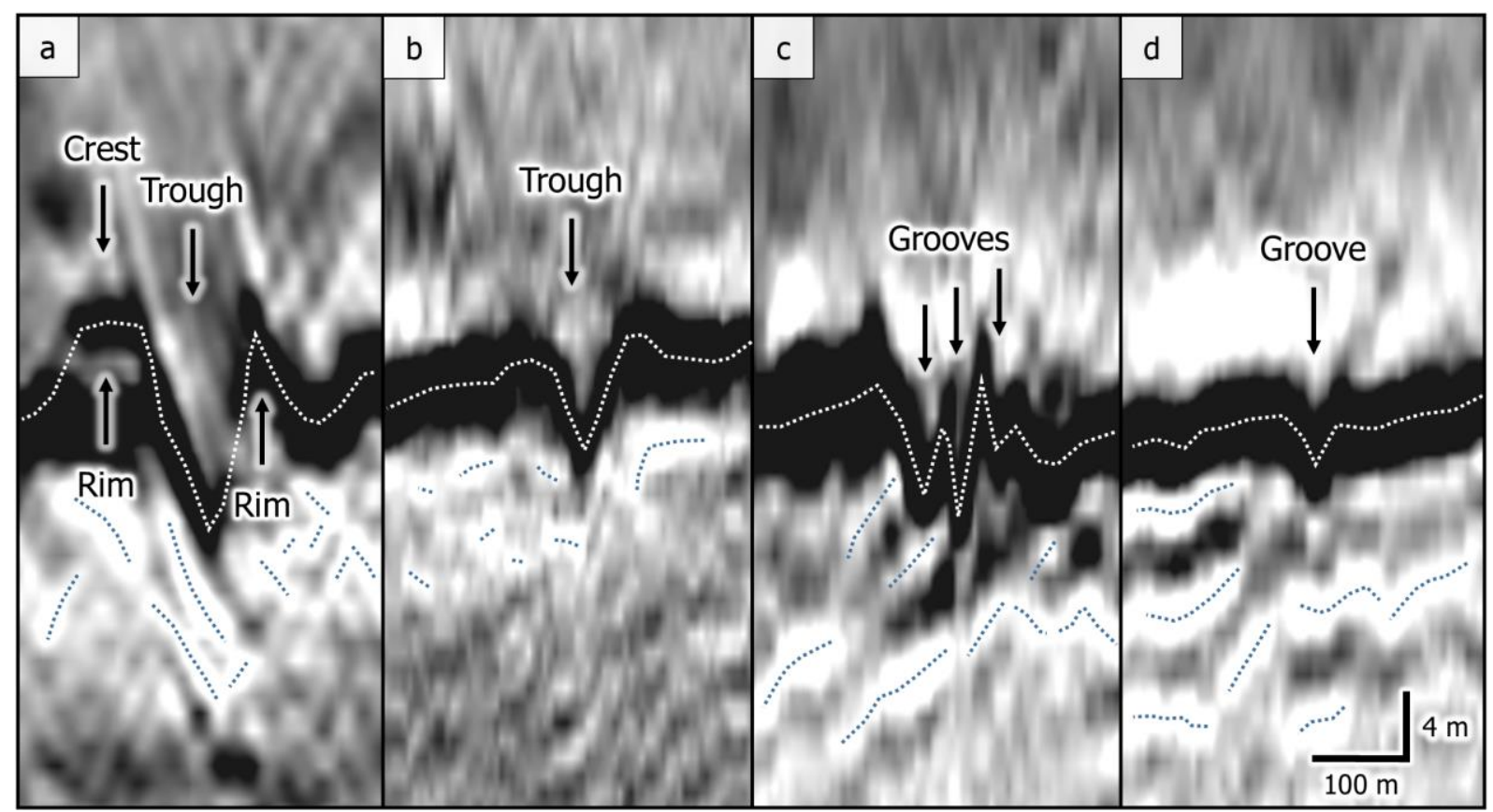

Fig. 7. P-Cable seismic profiles perpendicular to linear grooves showing the different expressions of mega-scale glacial lineations (MSGL) along URU (indicated by white stippled line). a) MSGL with large rims. b) MSGL with small rims. c) MSGLs with densely-spaced parallel glacial grooves. d) Single, narrow MSGL without ridges. Deformed layers below the MSGLs are highlighted in blue. Profile locations are indicated in Fig. 6.

\subsubsection{Shear band ridges}

Description: Forty N-S-oriented regular ridges are identified in several areas west of a shear margin moraine identified atop URU (Fig. 6) (Bellwald et al., 2018a). These 1-5 m high ridges have wavelengths of $~ 50-100 \mathrm{~m}$, and can be followed for c. $1 \mathrm{~km}$ (Figs. $8 \mathrm{a}, \mathrm{b}, \mathrm{c}$ ). The ridges commonly dip westwards, and their positive-amplitude reflections can be traced below URU (Fig. 8b). Most of these ridges can be related to polygonal faults within Lower Cretaceous bedrock below URU (Fig. 8b, c). these ridges to represent shear band ridges formed in the shearing zone of an active ice stream. The link 
321 with the underlying polygonal faults indicates an inherited structural geological preconditioning aspect.

322 Variations in the geology below URU are indicated by geophysical well analysis of the area (Faleide et

323 al., in review), and we suggest that structurally weaker rocks were probably more vulnerable to erosion

324 in a phase when the former Barents Sea Ice Stream was predominantly flowing north-southwards (Figs.

$3258 \mathrm{~d}, \mathrm{e})$. The thrust-and-fold belts could have formed by a similar ice-stream configuration as the one

326 forming the shear margin moraine (predominantly N-S-wards) (Bellwald et al., 2018a), as they only

327 occur to the west of the moraine. The dip of the strata could also be caused by the overloading ice stream

328 itself, producing similar landforms as the push moraines of Nørre Lyngby formed by ice-marginal

329 deformation (Pedersen, 2012). Thrust sheets of similar dimensions (c. $10 \mathrm{~m}$ in height with a spacing of

$330200 \mathrm{~m}$ ) are identified in the Jasmund Glacitectonic Complex, where they are suggested to be formed by

331 local ice push in a proglacial rather than subglacial environment (Gehrmann and Harding, 2018). As

332 faults are locations of fluid accumulation (Weinberger and Brown, 2006; Cook et al., 2008) and gas

333 hydrate accumulations are wide-spread in the Barents Sea (e.g., Serov et al., 2017), the troughs of the

334 ridges might have been generated by ice freezing on the subsurface gas hydrates at the base of the ice

335 stream. An alternative interpretation of the landforms could be ribbed moraine landscapes, which are

336 large ridges of sediment produced transverse to ice-flow directions (Kleman and Hättestrand, 1999;

337 Dunlop et al., 2008). 


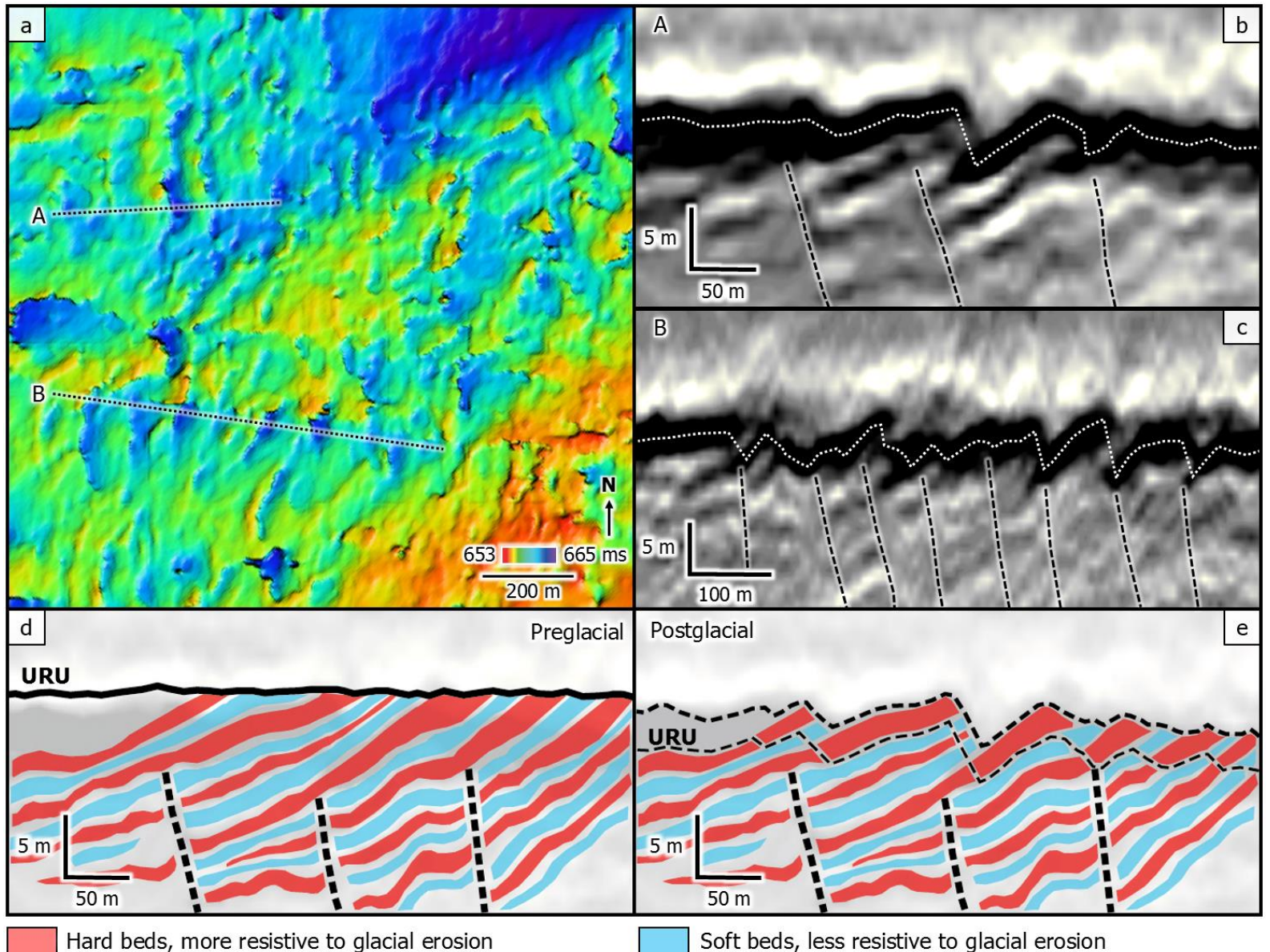

Fig. 8. Shear band ridges at URU. a) Structure map of shear band ridges, located in the west of the shear margin moraine. $\mathbf{b}+\mathbf{c})$ P-Cable seismic profiles across shear band ridges at URU. Polygonal faults below URU (white stippled line) correlate with the troughs. $\mathbf{d}+\mathbf{e}$ ) Sketch illustrating the formation of shear band ridges. Smooth URU before the last glaciation, with different bands of inclined Lower Cretaceous bedrock outcropping. Glacial erosion was more efficient along soft beds, and formed an URU locally dominated by ridges consisting of hard beds. See Fig. 6 for location.

\subsubsection{Rhombohedral ridges and depressions}

Description: A series of 50-150 m wide depressions with 2-5 m high ridges surrounding most of these is identified in the thermokarst-dominated area of the cube (Figs. 6, 9). These ridges, seven in total, have a reticulate or rhombohedral planform geometry, and occur both as single landforms and in networks. 
The depressions are not flat, but consist of predominantly eastwards-dipping beds. The deepest part of these roughly circular expressions coincides with the location of polygonal faults.

352

Interpretation: Ridges with similar geometries offshore Svalbard are interpreted to have been formed by the filling of basal crevasses with deforming diamictic sediments at the marine margin of a surging ice cap (Dowdeswell and Ottesen, 2016; Dowdeswell et al., 2016). Similar landforms at the seabed of the central Barents Sea have been interpreted as polygonal stagnation ridges, indicating crevassesqueezing during ice-stream stagnation after surging (Andreassen et al., 2014; Bjarnadóttir et al., 2014).

Crevasse-squeezing or deformation of diamictic sediments are rather unlikely processes for the observed rhombohedral ridges, as URU reflects here hard sedimentary bedrock rather than reworked glacial sediments (Fig. 9b). The association between underlying polygonal faults and the deepest depressions of the rhombohedral ridges indicate a link with pre-existing structural elements rather than with filling of ice-stream crevasses. Gas hydrates are documented to accumulate along polygonal faults (Weinberger and Brown, 2006; Cook et al., 2008), and thus ice frozen to the Lower Cretaceous bedrock could have removed material along the depressions of the rhombohedral ridges (Fig. 9c). Freezing and thawing permafrost leaves voids in fragmented bedrock, and we suggest surface collapses to create the deepest depressions along the polygonal faults (Fig. 9d). Thus the gas hydrates could have had a similar role as frost blisters formed by injection ice (Åkerman and Boardman, 1987) or permafrost for thermokarst lakes and pingos (Mackay, 1998; Grosse et al., 2013). The dimensions of the rhombohedral ridges and depressions correlates with the extent of 2327 thermokarst lakes within the Yedoma landscapes of the Lena Delta (Morgenstern et al., 2011).

The presence of an ice sheet does not allow vertical fluid dissipation, but rather adds fluids into the underlying substrate (Grasby et al., 2000). Water could even be introduced by ice streams and by permafrost, causing or contributing to weakening of the paleo-seabed. We interpret the rhombohedral ridges along URU to consist of bedrock and to be the product of structural failure with water present in the underlying rocks (Figs. 9c, d). The softer reflections below could indicate gas accumulations still present today (Figs. 9b, d). Alternative explanations are collapsed pingos or pockmarks. The ridgedepression morphologies show similarities to collapsed pingos surrounded by collapse ramparts 
(Mackay, 1998). Pingos are elongate to circular, ice-cored mounds, which form periglacial in thermokarst landscapes, and reach heights of some tens of meters before they collapse (Mackay, 1998; Soare et al., 2008). Bjørnelva, a braided river along URU (Fig. 6) (Bellwald et al., in review), shows that expressions at this glacial unconformity can also have formed in a subaerial environment. Thus, the rhombohedral ridges could represent ancient thermokarst lakes or collapsed pingos.

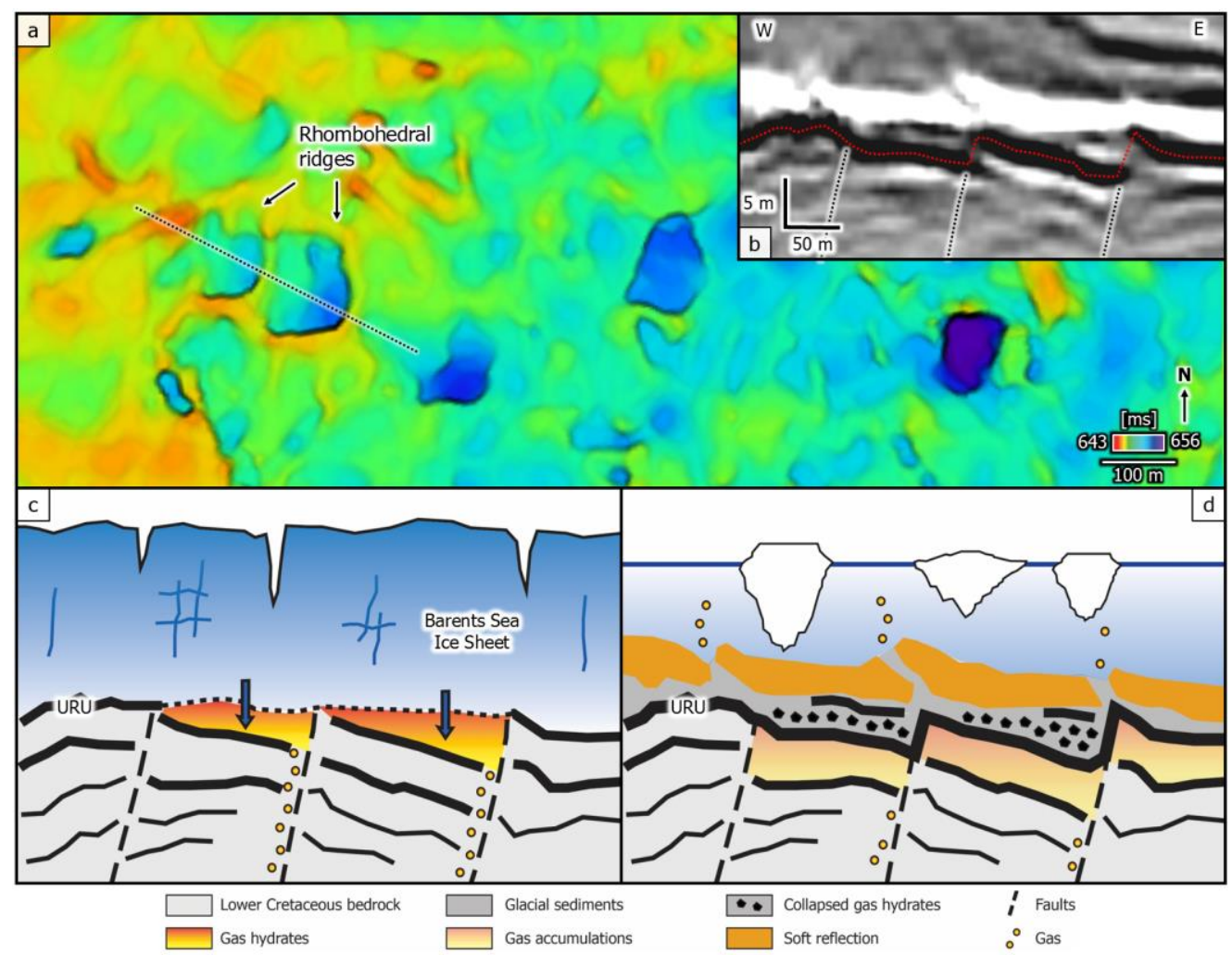

Fig. 9. Rhombohedral ridges at URU. a) Structure map. See Fig. 6 for location. b) P-Cable seismic profile across rhombohedral ridges. URU reflection (red stippled line) and polygonal faults (black stippled lines) are indicated. c) Formation of rhombohedral ridges. Gas migrating along shallow faults is trapped in deformed strata below URU and forms gas hydrates when the area was covered by the Barents Sea Ice Sheet. The ice sheet is suggested to be frozen due to gas hydrate accumulations that act as sticky spots. d) Formation of rhombohedral ridges. Gas hydrates melt during deglaciation, and the gas-hydrate collapse forms rhombohedral ridges and depressions. The infill of the rhombohedral depressions is dominated by sediments previously hold together by existing gas hydrates. Soft reflections below URU still indicate gas accumulations, but gas is supposed to escape periodically. Inconsistencies along the soft reflection above URU could represent fluid escape pathways. 
394

395

396

397

398

399

400

401

402

403

404

405

406

407

408

409

410

411

412

413

414

415

416

417

Description: Two groups of ridges form positive-relief landforms relative to the surrounding URU. The 73 ridges of the first group are 2-5 m high with a smooth top, 50-100 m wide, closely-spaced and symmetric in cross profiles (Fig. 10a). These semi-linear ridges commonly confluence and create circular to oval-shaped depressions. The subsurface of these ridges has an acoustically chaotic signature, with deformed beds.

The second group consists of 51 ridges with heights of 1-5 m and sharp tops, widths of 20-100 m, and asymmetric cross-profiles with steeper flanks in the east (Fig. 10b). These ridges can horizontally be traced for 200-1000 m, and often consist of several 50-200 m-long ridge segments. The horizontal spacing of this parallel, trough-transverse second group of ridges varies from 100 to $300 \mathrm{~m}$, and the base of their eastern flank correlates with polygonal faults below URU (Fig. 10b). The subsurface of these ridges is characterized by eastwards-dipping positive-amplitude reflections.

Interpretation: Referring to similar expressions at the base of Bråsvellbreen (Solheim and Pfirman, 1985), the first group of ridges could be formed by squeezing soft diamictic sediments into basal crevasses and hollows. Similar longitudinal banding has been observed in the Central Bjørynøyrenna (Bjarnadóttir et al., 2014), where such landforms have been interpreted as linear stagnation ridges formed by crevasse filling and indicate ice stagnation. Ribbed moraines, which are fields of till ridges produced transverse to ice flow (Kleman and Hättestrand, 1999; Dunlop et al., 2008), are other features indicating former frozen-bed features, with detachment and rotation similar to the first type. Ribbed moraines consist of ridges that are mostly curved or anastomosing (Hättestrand and Kleman, 1999), but the ridges of ribbed moraines are higher and wider than the transverse ridges of this study (Hättestrand and Kleman, 1999). Similar to the rhombohedral ridges, this first group of transverse ridges reflects sedimentary bedrock. As these features dominate the thermokarst landscape, we interpret them to have a permafrost-related origin. A freezing-thawing dominated area is supported by the seismically chaotic, low-amplitude reflection in the subsurface of these ridges. 
418 The second group of ridges shows a similar geomorphology to suites of seabed moraines in Northern

419 Scotland (Bradwell and Stoker, 2016) and NW Spitsbergen (Burton et al., 2016), where these landforms

420 have been interpreted as recessional and retreat moraines. Ridges with steeper ice-proximal slopes have

421 been documented from a surging ice cap in Svalbard (Dowdeswell et al., 2016). As the expressions of

422 our study most likely consist of deformed bedrock, a process such as mobile sedimentary pushing or

423 submarine mud apron cannot explain the features. Flat-topped mounds partly aligned in chains have

424 been interpreted as glaciotectonic rafts in the Barents Sea (Andreassen et al., 2004; Andreassen et al.,

425 2007; Rüther et al., 2013). The absence of a clear base reflection, the geometry of the ridges themselves

426 and the link to the polygonal faults makes us suggest that they represent bedrock outliers, and not

427 deformed soft sediments. However, eastwards-dipping reflections below URU support glaciotectonic

428 deformation of Lower Cretaceous sedimentary bedrock below an east-west flowing Barents Sea Ice

429 Sheet (Fig. 10b). They could thus represent compressional ridges in bedrock related to periodical ice stagnation with a temporarily cold basal thermal regime. 


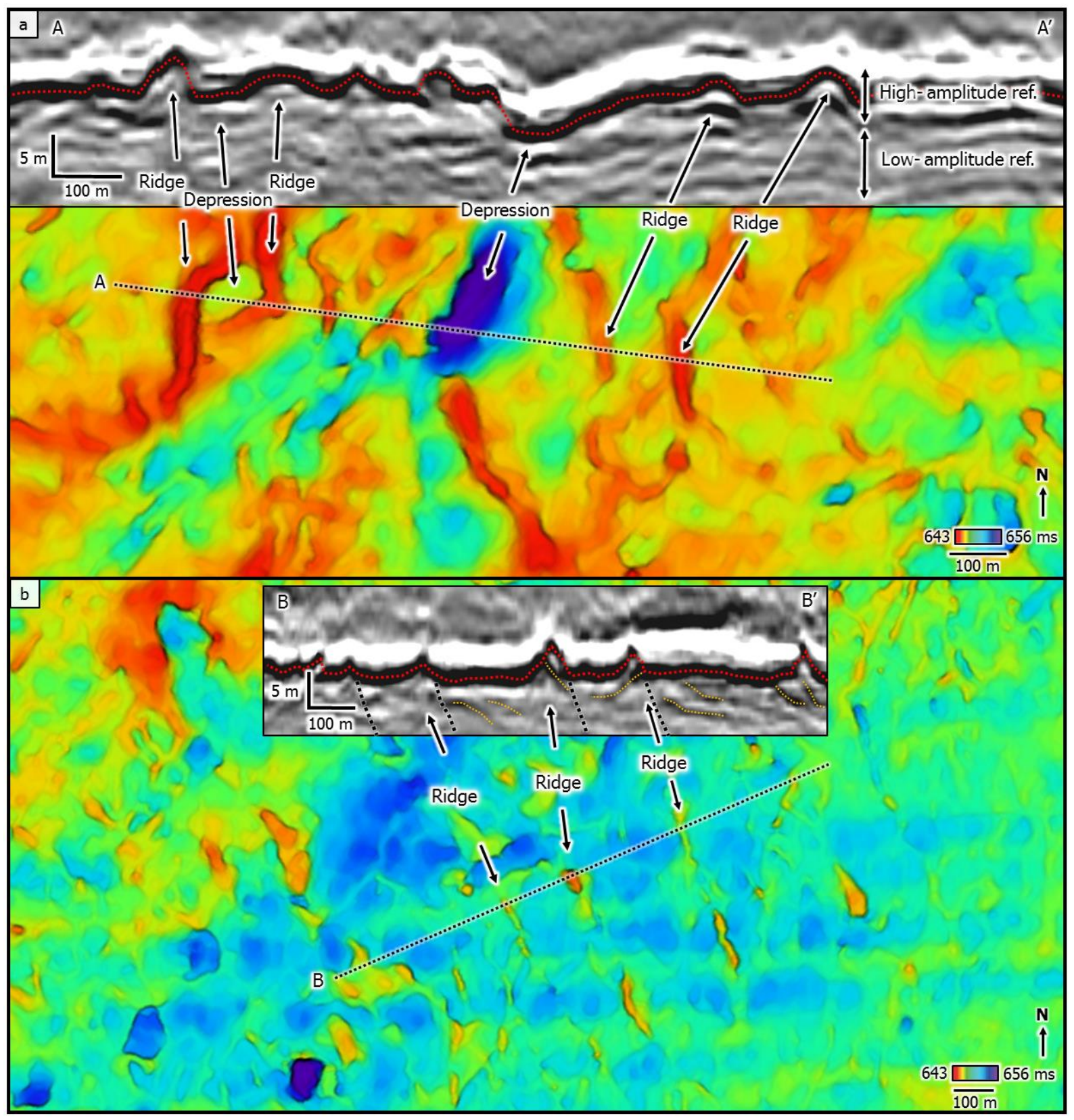

432 Fig. 10. Transverse ridges. See Fig. 6 for location. a) P-Cable seismic profile and structure map of first group of transverse ridges at URU. b) P-Cable seismic profile and structure map of second group of 434 transverse ridges at URU, which have asymmetric cross-profiles. 


\subsubsection{Iceberg ploughmarks}

438

Description: Five chaotically-oriented grooves with widths of c. $50 \mathrm{~m}$ and depths of c. $5 \mathrm{~m}$ are crosscutting some of the transverse ridges (Fig. 11, profile B). The grooves can be V-shaped or flatbottomed, and have $1 \mathrm{~m}$ high rises on both sides.

Interpretation: Variably-oriented curvilinear grooves are interpreted to be iceberg ploughmarks, formed by sediment ploughing by keels of grounded icebergs (Dowdeswell et al., 2008). The ploughmark shown in Fig. 11 is formed by a flat-bottomed iceberg. A correlation between gas sand and ancient iceberg ploughmarks was proposed by Gallagher and Braaten (1990), suggesting that sand was trapped in these shallow depressions. As the ploughmarks of this study are less than $5 \mathrm{~m}$ deep, we cannot draw conclusions about their infill.

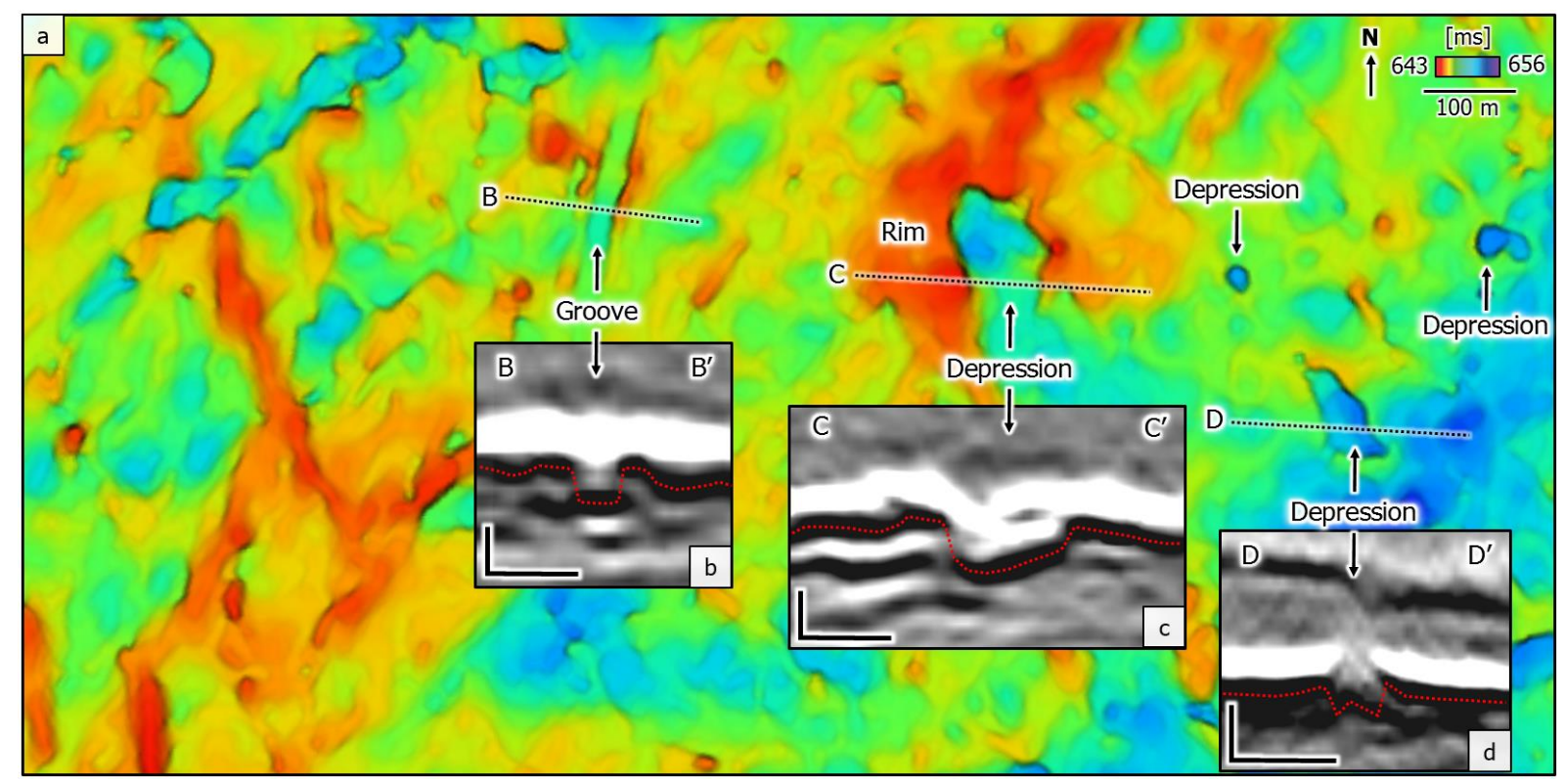

Fig. 11. a) Structure map of the thermokarst-dominated area with seismic profiles across different geomorphologies. See Fig. 6 for location. P-Cable seismic profiles show b) iceberg ploughmark, c) circular rimmed pockmark, and d) elongated rimmed pockmark. Smaller pockmarks are indicated as depressions in the structure map. Scale is $5 \mathrm{~m}$ in vertical and $100 \mathrm{~m}$ in horizontal dimension. 
455

Description: Semi-circular to circular and elongated, 20-100 m wide and up to $5 \mathrm{~m}$ deep depressions have been identified in the thermokarst-dominated area (Fig. 11). They are not completely flat at their bottom, and can have $\sim 1 \mathrm{~m}$ high rims. The continuous soft reflection atop URU, interpreted as a soft bed or gas-charged coarser-grained layer (Bellwald and Planke, 2018), is distorted at the locations of these depressions (Fig. 11, profiles B and C).

Interpretation: Rounded to oval-shaped depressions with diameters $<100 \mathrm{~m}$ are often related to subsurface fluid-flow, and interpreted as pockmarks (King and MacLean, 1970; Solheim and Elverhøi, 1985). Elongated pockmarks have their long axis orientation parallel to the prevailing bottom current direction (Farin, 1980; Bøe et al., 1998). Oval-shaped craters on the seabed of the northern Bjørnøyrenna are interpreted as giant craters etched into sedimentary bedrock of Triassic age (Andreassen et al., 2017). Circular pockmarks at URU have been identified in P-Cable data of the Snøhvit area (Tasianas et al., 2018). Following these interpretations, we suggest the rounded to oval depressions in our study area to be pockmarks formed after deglaciation. The presence of gas below URU is likely due to the location within the thermokarst landscape, and gas escape from frozen gas hydrates could act as a potential fluid source. Bellwald et al. (2018a) further mapped shallow gas accumulations and seabed pockmarks in this area. Interruptions in the soft reflection atop the pockmarks could indicate fluid escape events both before (Fig. 11b) and after (Figs. 11c, d) the deposition of this layer. Due to the size of the pockmarks, these would be rather high-magnitude degassing events.

\subsubsection{Hill-hole pairs}

Description: Six pairs of ridges and depressions are observed in the northwestern part of the study area (Figs. 6, 12). The c. $7 \mathrm{~m}$ deep depressions in the northwest of the study area are characterized by a steeper-dipping northern flank and a more gentle-dipping southern flank, and cover an area of c. 100,000 $\mathrm{m}^{2}\left(0.1 \mathrm{~km}^{2}\right)$ per depression (Fig. 12c). The ridges are elongated and trend NNE-SSW, with a maximal length of $1000 \mathrm{~m}$ and an average width of $200 \mathrm{~m}\left(0.2 \mathrm{~km}^{2}\right.$ in areal extent). The up to $5 \mathrm{~m}$ high ridges 
have average heights of $3 \mathrm{~m}$ and thin out southwards (Fig. 12d). While small depressions can be identified in conventional 3D seismic data, the ridges cannot always be imaged by this technology (Fig. 12a).

A pair consisting of c. $10 \mathrm{~m}$ deep depressions and rims rising c. $5 \mathrm{~m}$, but of much smaller extent than the mounds of hill-hole pairs documented before, has been identified in the south-west of the seismic cube (Fig. 12e). The rim consists of deposits which overthrusted URU in a southwest-wards direction (Fig. 12f). A feature with a similar depression and the same orientation, but lacking any rim, is identified to the east of this pair (Fig. 6).

Interpretation: Linked sets of individual depressions and adjacent ridges are interpreted as hill-hole pairs (Bøe et al., 2016). Hill-hole pairs are glaciotectonic features formed by rafting of subglacial hydrate-bearing sediment and shallow bedrock. The source depression is created by sediment slabs frozen on to the glacier bed. Transported with the overlying ice, the material is dumped close by and downstream. Subsequent melting and release cause the formation of these irregular hills (Bøe et al., 2016). The paired ridge and depression features are therefore interpreted as hill-hole pairs, formed when a grounded Bjørnøyrenna Ice Stream was locally frozen to its bed. The volume of excavated sediment $\left(0.1 \mathrm{~km}^{2} \times 7 \mathrm{~m}\right)$ approximately equals the deposit $\left(0.2 \mathrm{~km}^{2} \times 3 \mathrm{~m}\right)$ (Fig. 12b). The axes of hill-hole pairs are sub-parallel to inferred ice-flow directions, and we suggest them to originate during phases dominated by a NW-SE-flowing Bjørnøyrenna Ice Stream.

Hill-hole pairs in the Skagerrak are reported to be formed close to the main ice stream shear margin (Bøe et al., 2016). A shear margin moraine located in the east of the hill-hole pairs (Fig. 6b) in the Hoop Fault Complex area indicates a link between glacier shearing and hill-hole pairs. Slower flowing ice close to the shear margin (Bellwald et al., 2018a) probably facilitated freeze-on and glaciotectonic processes at the base of the glacier. While a hole of much smaller dimension is detectable in the conventional seismic data, the hill is not traceable there at all using conventional 3D seismic (Fig. 12a). The extent of a typical hill-hole pair in the study area $\left(0.3 \mathrm{~km}^{2}\right)$ is three magnitudes smaller compared to hill-hole pairs identified in Håkjerringdjupet, SW Barents Sea (Winsborrow et al., 2016) (Fig. 1b), 
506 and one magnitude smaller to the potential terrestrial hill-hole pair forming Lake Esrum Sø, located in 507 the glacial landscape of NE Sjælland (Pedersen and Boldreel, 2017).

508 Similar landforms as the smaller hill-hole pair (Fig. 12e) have been observed in the previously glaciated 509 Norwegian continental shelf (Rise et al., 2016) and in the Djuprenna, SW Barents Sea (King et al., 510 2016). Underlain by glacial till, King et al. (2016) interpreted the landforms as crescentic ridges formed 511 by calving and rotating icebergs. Rise et al. (2016), on the other hand, interpreted similar features as 512 hill-hole pairs, formed by glaciotectonic activity at hard bedrock. As URU is supposed to truncate Lower 513 Cretaceous bedrock, we follow Rise et al. (2016) and interpret these features as hill-hole pairs, noting 514 that the depressions may not always be associated with hills downstream. The hills comprise thrust515 block deposits (reworked Lower Cretaceous shale) sourced from the holes (Fig. 12e). A link between 516 the location of hill-hole pairs and shallow faults has previously been documented (Bellwald et al., 517 2018b). Correlations between hill-hole pairs and fault escarps and folds have also been discussed in terrestrial environments (Pedersen and Boldreel, 2017). 


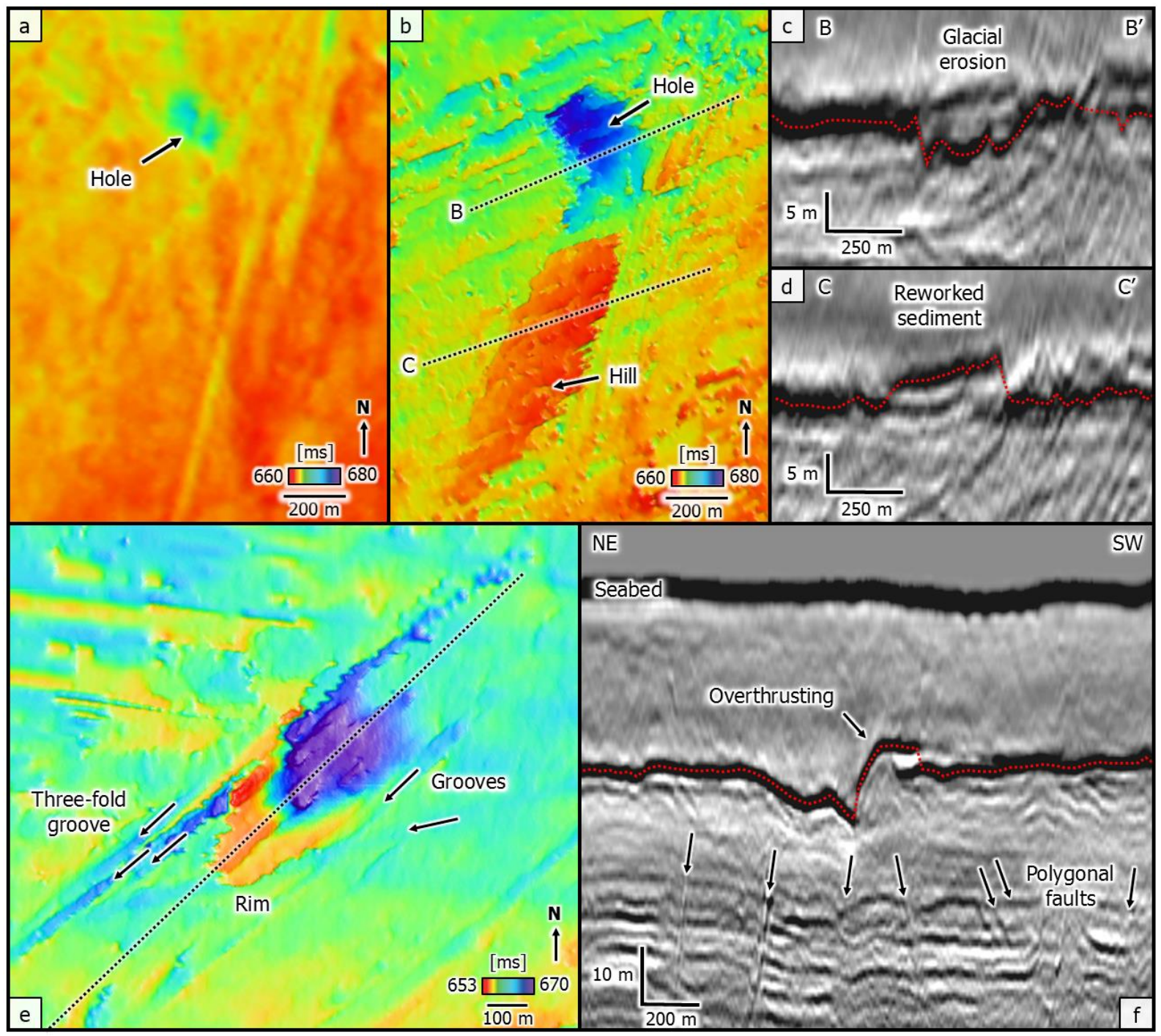

Fig. 12. Hill-hole pairs. See Fig. 6 for location. a) Structure map generated in conventional 3D seismic

521 data only showing the hole of a hill-hole pair. b) Structure map generated in P-Cable 3D seismic data

522 showing the complete hill-hole pair indicated in Fig. 12a. The footprints aligned parallel to the course

523 of the survey vessel (E-W) are artefacts related to the acquisition of the seismic data. c) P-Cable seismic

524 profile across the hole. d) P-Cable seismic profile across the hill, which is not visible in conventional

525 seismic data. e) Structure map generated in P-Cable seismic data showing a rimmed hill-hole pair.

526 Arrows indicate glacial grooves. f) P-Cable seismic profile along the hill-hole pair shown in Fig. 12e.

527 Note thrust of sediment block from the base to the ice flow direction. 


\section{Discussion}

530

531

532

533

534

535

536

537

538

539

540

541

542

543

544

545

546

547

548

549

550

551

552

553

\subsection{URU landform assemblage and its implications}

The P-Cable data reveal a well-preserved URU landform assemblage with no to minimal morphological alterations by subsequent overriding ice sheets for expressions identified at that paleo-surface. The landscapes at URU therefore contain key evidence on the configuration and evolution of the Barents Sea Ice Stream. Glacial landforms at URU consist of glacio-tectonically deformed and reworked bedrock, glacio-erosive bedrock imprints, permafrost-degraded depressions, fluvial channels, and fluidflow related features (Fig. 13).

The URU landform assemblage in the Hoop Fault Complex area reveals a complex and dynamic former Barents Sea Ice Sheet, and is dominated by subglacial landforms that indicate several flow-switching events and changes in basal thermal regimes (Fig. 13). The Barents Sea has a low density of dates and ice-sheet pattern information on the contemporary seabed (Hughes et al., 2016), and reliable ages for different streaming events at URU are not existing. However, the URU landform assemblage indicates four main ice-flow directions prior to the formation of glacial till atop URU and the glacial landforms shaping the contemporary seabed (Fig. 13):

(1) E-W-directed ice flow indicated by glacial lineations of streaming set 1 ,

(2) ENE-WSW-directed ice flow indicated by glacial lineations of streaming set 2, a topographic high, ridges parallel to the topographic high and transverse ridges in the area southeast of the topographic high,

(3) NNE-SSW-directed ice flow indicated by a third set of (overprinting) glacial lineations (streaming set 3), streamlined hill-hole pairs, shear band ridges, and a shear margin moraine, and

(4) NE-SW-directed ice flow indicated by a fourth set of glacial lineations (streaming set 4), and streamlined hill-hole pairs. 
These landform assemblages lead us to draw conclusions about the genesis of different types of terrains. Streamlined terrains in the west of the study area have been formed by erosion of the substrate related to basal sliding in the thawed-bed zone when the glacier bed was at the melting point. The four sets of mega-scale glacial lineations (MSGLs) indicate four periods of grounded fast-flowing ice streams and subsequent sediment deformation, with set 1 representing the relatively oldest and set 4 the relatively youngest period. These ice-stream flow-sets have been identified in several larger seismic cubes of the region, and helped to reconstruct the paleo-ice-sheet configurations of the Barents Sea Ice Sheet (Piasecka et al., 2016). MSGLs with length:width ratios >10:1 are indicative of fast ice flow (Stokes and Clark, 2002), and the MSGLs of this study thus indicate fast ice-flow. We conclude that hill-hole pairs have been formed by plucking of large blocks of material from Lower Cretaceous bedrock (www.npd.no). Therefore, we suggest temporary and locally frozen-bed conditions for ice-streaming flow-set 3 and 4, and ice movement of the Barents Sea Ice Sheet to primarily have occurred by internal deformation of ice. The hill-hole pairs deposited within the frozen-bed zone have been preserved more or less unmodified (Fig. 12). Subglacial landforms identified in the P-Cable data indicate polythermal subglacial regimes along URU, which is evidence that cannot be found at the seabed of the area (Bellwald et al., 2018a).

Different sets of MSGLs and a shear margin moraine (Piasecka et al., 2016; Bellwald et al., 2018a) indicate that the study area was located in a shear zone between ice streams and slower-flowing regions of an ice sheet. Glacier-thrust terrains in Saskatchewan and Alberta are interpreted to be located along former ice-marginal positions (Moran et al., 1980). Meter-scale glacial landforms such as shear band ridges and hill-hole pairs (Figs. 8, 12) support this setting to be dominated by glacial shearing.

Streamlined bedrock features may survive wet-based reoriented ice flow for long periods of time, in contrast to till lineations (Kleman and Borgström, 1996). Thus, we suggest the positive-amplitude reflection defining URU is mainly representing the contrast between bedrock and glacial sediments, and only occasionally reflecting underlying glacial till (e.g., rim of MSGL in Fig. 7a). The hill-hole pairs and the second type of transverse ridges are examples where the URU reflection most likely represents glacio-tectonically deformed sediments (Figs. 10b, 12). 
Topography and water depth have previously been discussed to partly control subglacial landforms (Anandakrishnan et al., 1998; Philipps et al., 2010; Winsborrow et al., 2010). The URU surface of the study area is a slightly dipping surface, and water depth can be ruled out as a controlling factor for the variety in the URU landform assemblage. However, topographical elements such as the NE-SWoriented high are supposed to have affected paleo-ice streaming and the resulting landforms.

The locations of shear zones are reported to be controlled by topography in previous studies (Kleman and Glasser, 2007). The topographic high along URU, which has a glaciotectonic or structural origin, could thus control the location of ice shearing in the study area. The thermokarst landscape in the southeast of the cube excludes streamlined subglacial landforms, and supports more stagnant glacial ice with permafrost in the subsurface (Fig. 13).

Holes interpreted as excavated frozen-bed patches are suggested to be important for the stability of ice sheets (Kleman and Glasser, 2007; Stokes et al., 2007), as they act as localized sticky spots and affect the basal resistance. Such sticky spots are reported to coincide with subsurface shallow gas accumulations and related to gas hydrates (Winsborrow et al., 2016). Desiccating gas hydrates are suggested to strengthen the subglacial sediment, promoting high traction, which regulates ice-stream flow (Winsborrow et al., 2016). Present-day pressure and temperature conditions in the Barents Sea are outside the stability field of methane hydrates (Tishchenko et al., 2005). However, high-pressure and low-temperature conditions favoring gas hydrate formation could certainly have prevailed beneath the Barents Sea Ice Sheet. Gas migration from Jurassic hydrocarbon reservoirs, such as the Gemini North (Polteau et al., 2018), and linked to the built-up of polygonal faults would have favored the generation of widespread gas hydrates subglacially. The presence of strong seismic reflections with a phasereversed polarity compared with seabed reflections has been interpreted as free gas accumulations in the subsurface sediments (Fig. 14) (Andreassen et al., 2017). The presence of gas hydrates has been suggested for the formation of the hill-hole pairs, and the rhombohedral ridges and depressions (Figs. 9, 12).

Several 10s of meters $(>30 \mathrm{~m})$ of bedrock below URU are characterized by folded, faulted and overthrusted reflections (Figs. 7, 14), favorably within 100-300 m wide blocks laterally defined by 
608 polygonal faults (Fig. 14). Proglacial stacking and folding patterns have been described in terrestrial 609 archives (Aber, 1982; Houmark-Nielsen, 1988). We suggest that the Barents Sea Ice Stream most likely 610 deformed the Lower Cretaceous bedrock below URU down to at least $30 \mathrm{~m}$ during multiple glacial 611 advances. Similar geometries as the glacio-tectonically deformed strata in the Lower Cretaceous of this 612 study (Fig. 14) are conjugate normal faults developed in the Lønstrup Klint Formation with an offset of 613 about $1 \mathrm{~m}$ (Pedersen, 2005).

614 We suggest a strong link between transverse ridges, rhombohedral ridges and hill-hole pairs with 615 variations in the underlying geology (Figs. 9, 10, 12). The geometry and location of landforms expressed 616 at URU have previously been discussed to be defined by deeper faults (Bellwald et al., 2018b), and 617 associations between glacial landforms and faults have also been suggested in terrestrial outcrops 618 (Pedersen and Boldreel, 2017). The depressions of hill-hole pairs and rhombohedral ridges indicate that 619 the Barents Sea Ice Sheet froze down to a bedrock depth of 5-10 m (Figs. 9, 12). Mechanical fracturing 620 related to unloading is reported to increase porosity, permeability and create fluid migration pathways 621 (Mohammedyasin et al., 2016). This could be a possible explanation for the pockmark formation atop 622 URU. 


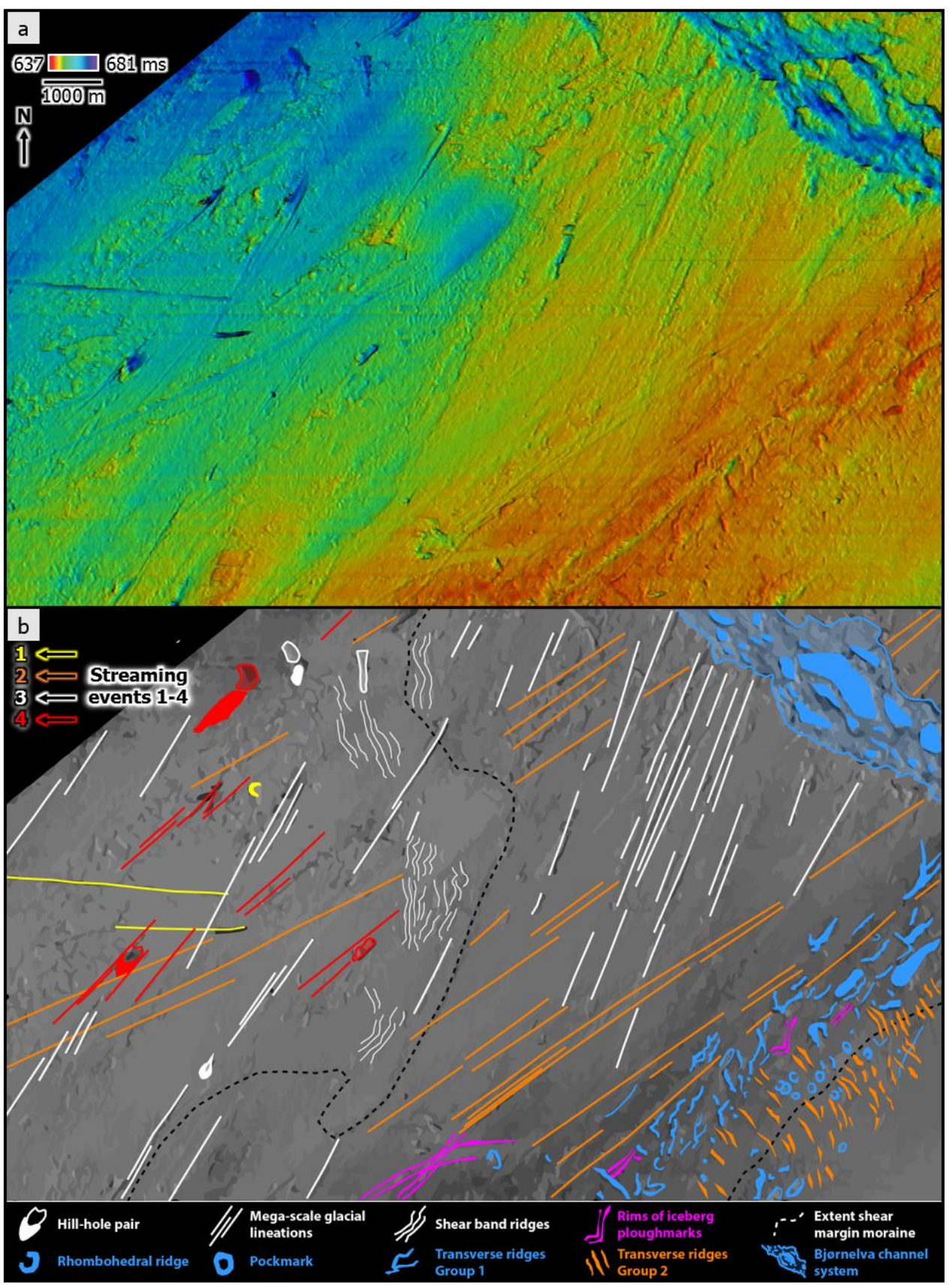

624 Fig. 13. Glacial landforms associated to four ice-streaming events (SE 1-4) identified in this study. a) URU structure map. b) Interpreted URU structure map. SE1 correlates with flow-set 1 of Piasecka et al. (2016), 2 with 3, 3 with 2, and 4 with 4. Hill-hole pairs indicate stages when the Barents Sea Ice Sheet was temporarily frozen to the ground. The topographic high and the thermokarst landscape are formed related to the NE-SW-oriented ice-streaming event (SE2). These landforms indicate permafrost and partly frozen basal ice in the SE of the cube. The topographic high most likely acted as a pinpoint for the formation of the shear margin moraine during SE3. Evidence of SE4 can only be found in the west of the cube. During SE3 and SE4, the Barents Sea Ice Sheet was locally frozen to the ground. 


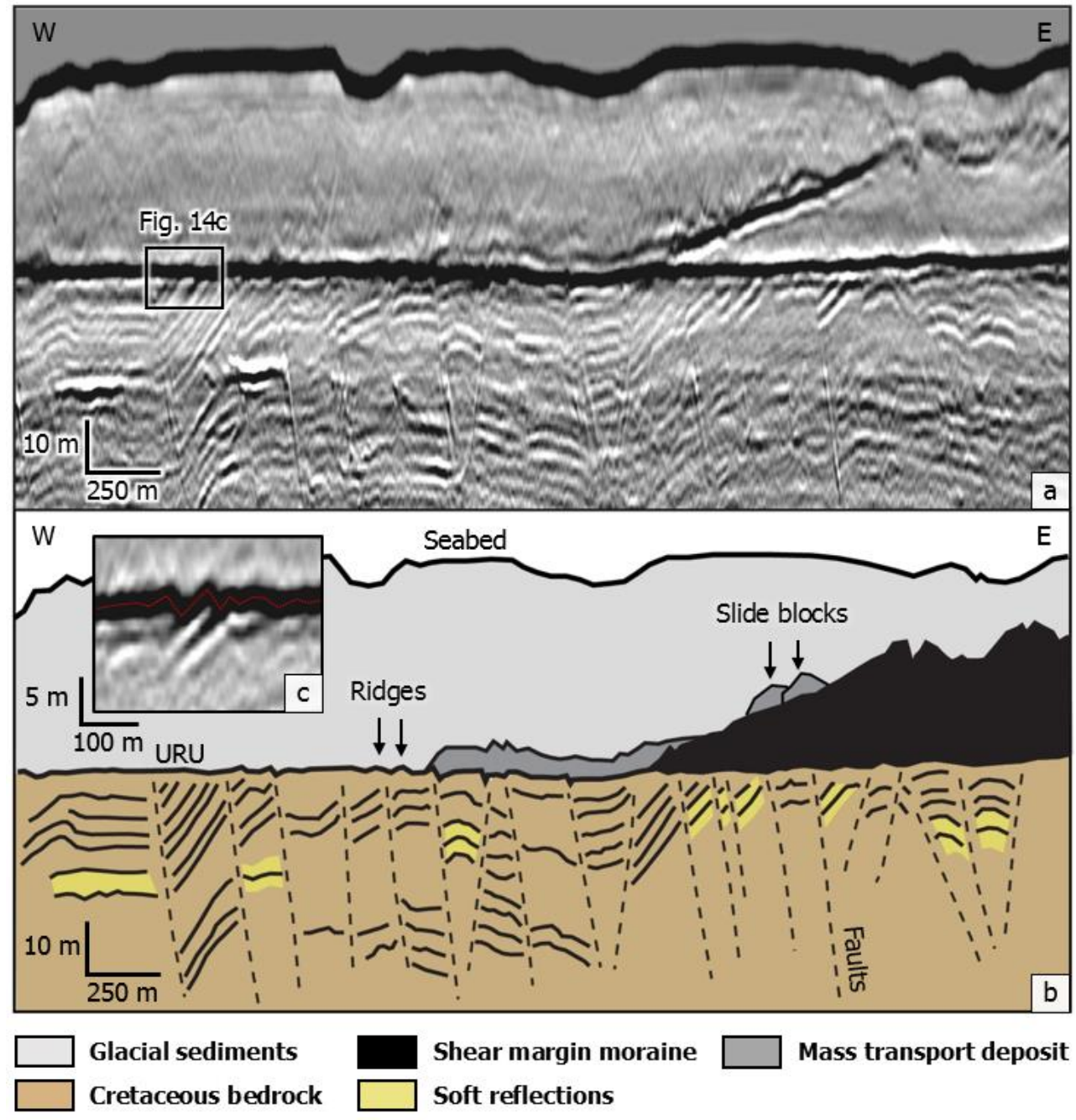

Fig. 14. Glacio-tectonically deformed strata below URU. a) P-Cable seismic profile. b) Interpreted seismic profile. Shear band ridges are identified west of the shear margin moraine. Glaciotectonic deformation can be identified down to $>30 \mathrm{~m}$ below URU. Folding and faulting of underlying bedrock preferentially occurred within blocks laterally defined by polygonal faults. c) Expression of shear band ridges in P-Cable 3D seismic profile.

\subsection{What do high-resolution $3 D$ seismic data add to the understanding of glacial processes?}

639 High-resolution 3D seismic data allow to make conclusions about the degree of preservation of meter640 scale glacial landforms at a paleo-surface, which reveal a complex and dynamic ice sheet. The data help 641 to evaluate if the URU reflection represents a contrast between sedimentary bedrock, glacio-tectonically 642 deformed sediments, or glacial sediments. The geometries and the links with the subsurface of these expressions cannot be interpreted in conventional seismic data (Figs. 4, 5). Structures as small as $1.5 \mathrm{~m}$ 
can be vertically resolved in P-Cable data at URU depths, which is up to five times higher than conventional 3D seismic data. While geological structures with horizontal extensions of less than $12 \mathrm{~m}$ cannot be resolved in conventional 3D seismic data, P-Cable 3D seismic data have a horizontal resolution of c. 5-6 m (Figs. 15, 16). Such a horizontal resolution is comparable to conventional keelmounted multi-beam echosounders (Bellwald et al., 2018a), and shows that buried surfaces can be mapped in seabed-quality using high-resolution 3D seismic data. Thereby we can image paleolandscapes in a quality comparable to landscapes imaged on GoogleEarth (Figs. 15c, 16c). This highresolution imaging allows to use modern landforms as analogues for processes active in the formation of structures identified in seismic data (Figs. 15c, 16c).

High-resolution 3D seismic data allow to map thermokarst landscapes (Figs. 6, 10). Thermokarst incorporates the presence of permafrost, which include frozen ice and gas hydrates (Kvelvolden, 1988; Kargel, 1995; Hassol, 2004). Abundant gas-hydrate accumulations are proposed to exist beneath the Antarctic and Greenland ice sheets (Wadham et al., 2012; Wallmann et al., 2012), and their release can occur in a catastrophic way (Kennett et al., 2003). Gas hydrates have been discussed for the formation of rhombohedral ridges and hill-hole pairs based on the P-Cable data of this study (Figs. 9, 12). The observation of large pockmarks at URU (Fig. 11) supports large quantities of gas and gas hydrates at the time of the URU formation. Circular to elongated lakes in Northern Siberia have a thermokarst origin (Fig. 15) (e.g., Morgenstern et al., 2013), and we infer similar conditions for the formation of rhombohedral ridges and the thermokarst-dominated landscape in general. However, the fact that thermokarst lakes usually have flat floors and lack rims (e.g., Soare et al., 2008) shows that such analogues have to be applied with caution.

While multiple sets of glacial lineations mapped in conventional 3D seismic data of the Hoop Fault Complex area indicate thawed glacier beds (Fig. 1b) (Piasecka et al., 2016), the identification of hillhole pairs in P-Cable data indicates a polythermal regime at the base of the Barents Sea Ice Sheet during multiple streaming events (Fig. 13). The association between shearing-related landforms and the shear margin moraine (Bellwald and Planke, 2018) highlight that freeze-on processes at the base of the ice 
sheet favorably have occurred in shearing zones, which has also been suggested for streamlined ridges

671 and depressions in the glacial sediment of the Norwegian Skagerrak (Bøe et al., 2016).

672 Ice-streaming events 1 and 4 correlate with previous chronologies (Piasecka et al., 2016) (Fig. 14). The

673 ice-streaming flow-set 2 of this study can be associated with ice-streaming event 3 of that study, and

674 ice-streaming flow-set 3 with ice-streaming event 2. MSGLs of ice-streaming event 2 below the

675 moraine, which is formed related to ice-streaming event 3, make us conclude that high-resolution 3D

676 seismic technologies can help to improve the relative chronology of the area. Ice-streaming event 4 to

677 be the last event is further supported by NE-SW-directed MSGLs identified on the top of the shear

678 margin moraine (Bellwald and Planke, 2018).

679 Trough-transverse ridges, imaged by structure maps and the use of seismic attributes (Fig. 16a), correlate 680 with polygonal faults identified in high-resolution 3D seismic data and highlight the inherited structural 681 geological aspect for landform generation. The example of transverse ridges shows that individual sets 682 of ridges can be linked together using the peak seismic amplitude (Fig. 16b), and that these ridges occur 683 in bands. Moraines along the SW Finnish coast show very similar expressions as the flow-transverse 684 ridges of this study (Fig. 16c). Thus, the transverse ridges could also consist of a thin layer of glacial 685 till, with a vertical extent below the resolution limit of this study.

686 Improvements in high-resolution 3D seismic technologies allow to visualize landforms with a lateral 687 resolution of $3 \mathrm{~m}$ (Lebedeva-Ivanova et al., 2018). Such a configuration has been used for the 688 neighboring Wisting area (Fig. 1b), and is supposed to image features even smaller than those of this 689 study in future. 


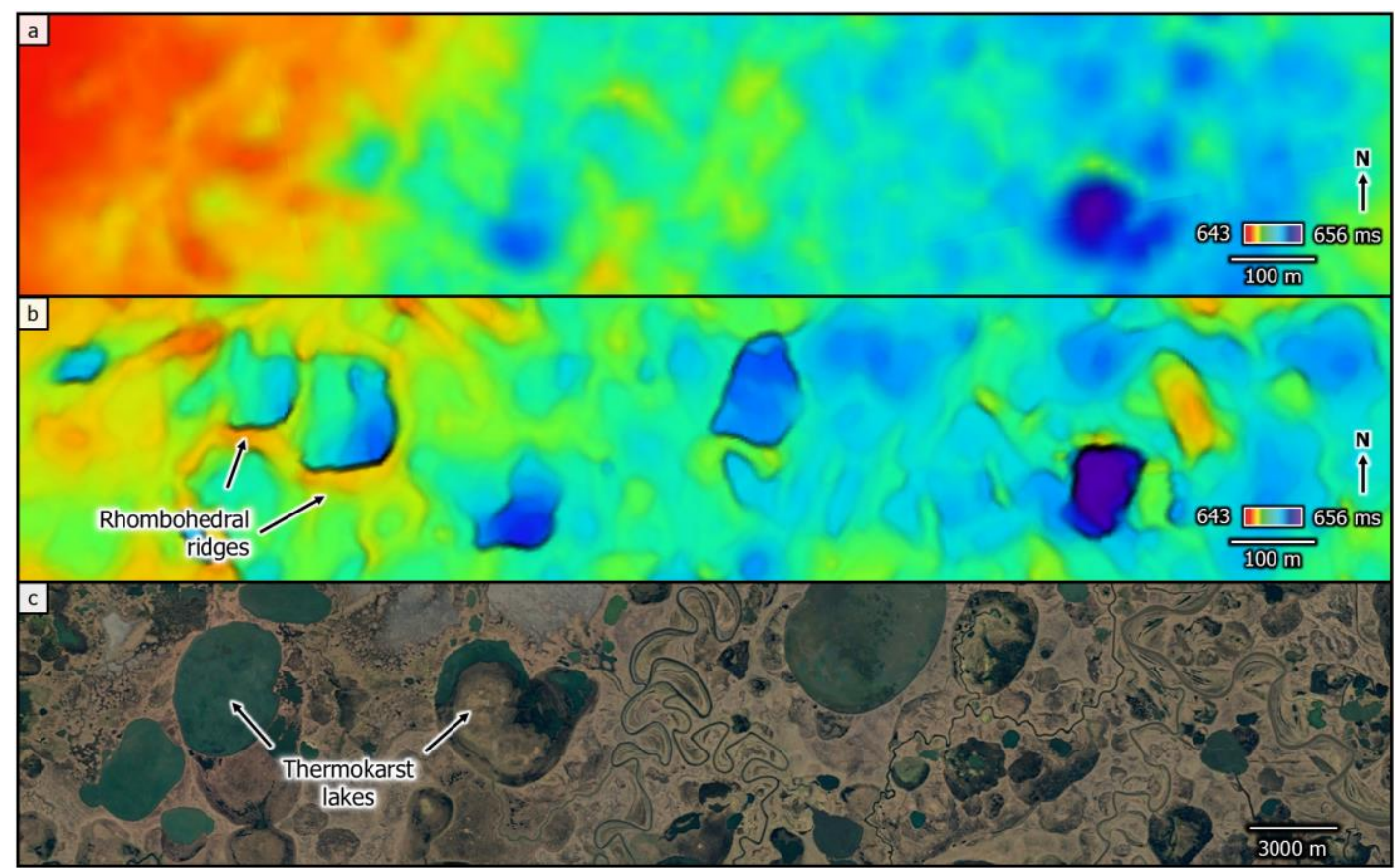

691 Fig. 15. Thermokarst landscapes identified in different technologies. a) Structures identified in conventional 3D seismic data. b) Structures identified in P-Cable 3D seismic data at the same location as Fig. 15a. c) Thermokarst lakes of the Lena Delta as analogue for thermokarst landscape identified in P-Cable data. Image from GoogleEarth.

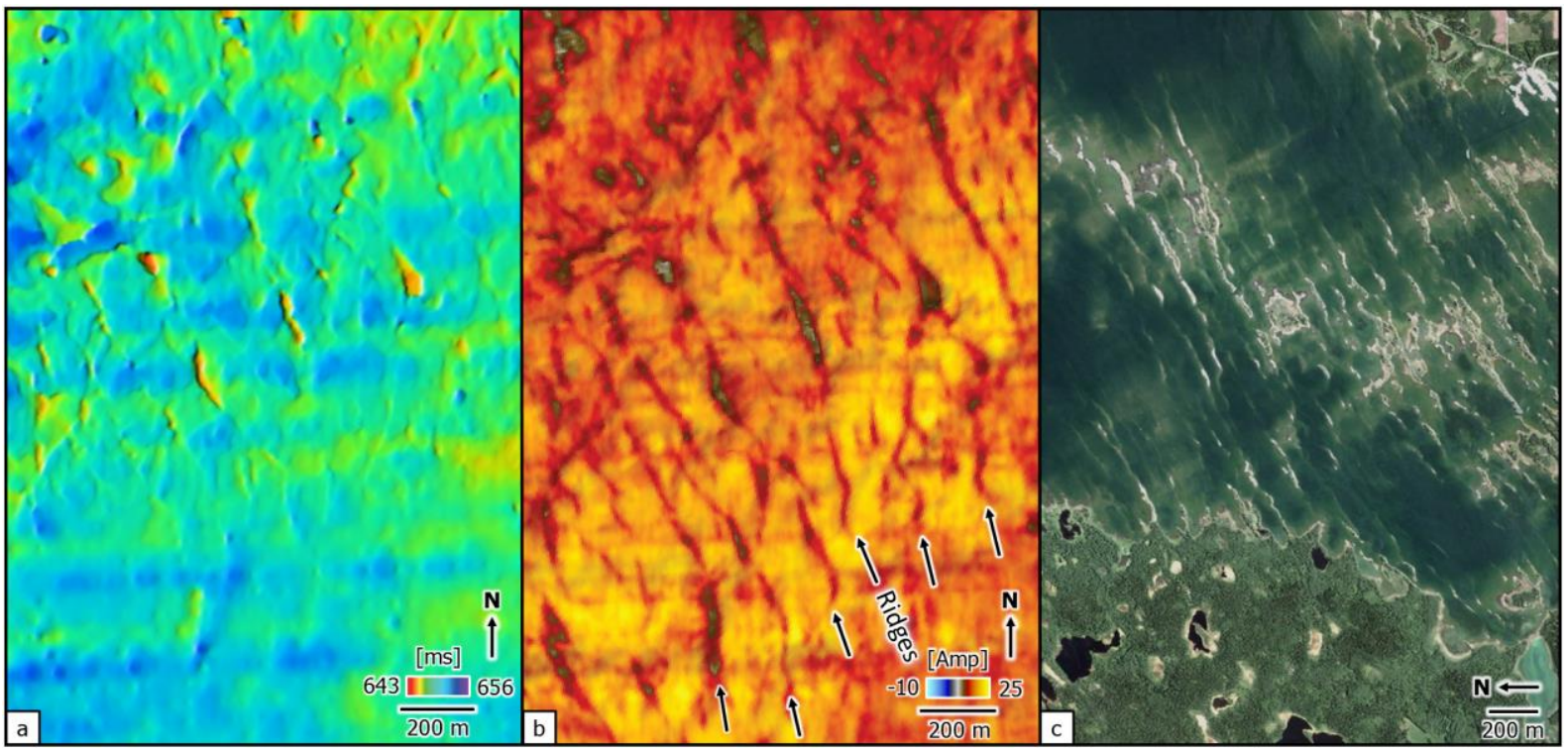

Fig. 16. Analogues of flow-parallel ridges imaged at URU. a) Structure map using P-Cable 3D seismic data. b) Peak seismic amplitude of URU pick using P-Cable 3D seismic data. c) Moraines identified in Svedjehamn, SW Finland. Image from GoogleEarth. 


\section{Conclusions}

700

701

702

703

The complexity of buried Quaternary landforms has been successfully imaged using high-resolution 3D seismic data. Meter-scale horizontal and vertical resolution of the shallow subsurface of the SW Barents Sea allowed to image geological structures at Upper Regional Unconformity (URU) in a quality comparable to conventional multi-beam echosounders.

The URU geomorphology reveals a variety of landforms, which are indicative of ice-sheet erosion and the presence of permafrost and gas hydrates below. Four sets of mega-scale glacial lineations, with associated hill-hole pairs for two of them, give valuable information about ice-sheet dynamics and indicate polythermal regimes at the base of the ice sheet. Shear band ridges seem to reflect strata of different erosional resistivities. Hill-hole pairs and rhombohedral ridges indicate depths of 5-10 m for ice-sheet freezing, which could reflect the level of the paleo gas hydrate stability zone. Pockmarks with a variety of shapes represent the fluid-flow events sourced either directly from deeper Jurassic reservoirs, or from gas related to a gas hydrate seal below URU. Hill-hole pairs, rhombohedral ridges and shear band ridges all correlate with polygonal faults in the underlying geology. Thus, the highresolution P-Cable 3D seismic data show that the faults in the shallow subsurface have an important, inherited effect on the occurrence of glacio-tectonic features along URU. However, landforms related to ice-streaming, such as mega-scale glacial lineations, do not correlate with any faults, and depend on ice-streaming directions.

The loading and compaction of sediments by ice resulted in the imposition of Lower Cretaceous sedimentary bedrock. Sedimentary layers have subsequently been deformed within the uppermost $30 \mathrm{~m}$ below URU. The presence of permafrost and gas hydrates below URU is suggested based on landforms related to thermokarst, such as rhombohedral ridges, transverse ridges and pockmarks. 


\section{Acknowledgements}

722 We thank TGS, WGP and VBPR for allowing to publish the seismic data. S. Planke acknowledges the support from the Research Council of Norway (RCN) through its Centres of Excellence funding scheme, project 223272, while E.D. Piasecka and K. Andreassen acknowledge support from the RCN Centre of Excellence project no. 223259.

\section{References}

Anandakrishnan, S., Blankenship, D.D., Alley, R.B., Stoffa, P.L., 1998. Influence of subglacial geology on the position of a West Antarctic ice stream from seismic observations. Nature 394, 62-65.

Andreassen, K., Winsborrow, M.C.M., 2009. Signature of ice streaming in Bjørnøyrenna, Polar North Atlantic, through the Pleistocene and implications for ice-stream dynamics. Annals of Glaciology 50(52), 17-26.

Andreassen, K., Nilssen, L.C., Rafaelsen, B., Kuilman, L., 2004. Three-dimensional seismic data from the Barents Sea reveal evidence of past ice streams and their dynamics. Geology 32(8), 729732.

Andreassen, K., Ødegaard, C.M., Rafaelsen, B., 2007. Imprints of former ice streams, imaged and interpreted using industry three-dimansional seismic data from the south-western Barents Sea. In Davies, R.J., Posamentier, H.W., Wood, L.J., Cartwright, J.A. (Eds.). Seismic Geomorphology: Applications to Hydrocarbon Exploration and Production. Geological Society, London Special Publications 277, 151-169.

Andreassen, K., Winsborrow, M.C.M., Bjarnadottir, L.R., Rüther, D.C., 2014. Ice sream retreat dynamics inferred from an assemblage of landforms in the northern Barents Sea. Quaternary Science Reviews 92, 246-257.

Andreassen, K., Hubbard, A., Winsborrow, M., Patton, H., Vadakkepuliyambatta, S., Plaza-Faverola, A., Gudlaugsson, E., Serov, P., Deryabin, A., Mattingsdal, R., Mienert, J., Bünz, S., 2017. 
Massive blow-out craters formed by hydrate-controlled methane expulsion from the Arctic seafloor. Science 356, 948-953.

748

749

750

751

752

753

754

755

756

757

758

759

760

761

762

763

764

765

766

767

Attig, J.W., Mickelson, D.M., Clayton, L., 1989. Late Wisconsin landform distribution and glacier-bed conditions in Wisconsin. Sedimentary Geology 62, 399-405.

Åkerman, J., Boardman, J., 1987. Periglacial forms of Svalbard: a review. In: Boardman, J. (Ed.), Periglacial processes and landforms in Britain and Ireland, 9-25.

Bellwald, B., Planke, S., 2018. Shear margin moraine, mass transport deposits and soft beds revealed by high-resolution P-Cable three-dimensional seismic data in the Hoop Area, Barents Sea. Geological Society of London, Special Publications, 477.

Bellwald, B., Planke, S., Piasecka, E.D., Matar, M.A., Andreassen, K., 2018a. Ice-stream dynamics of the SW Barents Sea revealed by high-resolution 3D seismic imaging of glacial deposits in the Hoop area. Marine Geology 402, 165-183.

Bellwald, B., Planke, S., Polteau, S., Lebedeva-Ivanova, N., Hafeez, A., Faleide, J.I., Myklebust, R., 2018b. Detailed structure of buried glacial landforms revealed by high-resolution 3D seismic data in the SW Barents Sea. EAGE Extended Abstracts 2018.

Bellwald, B., Planke, S., Polteau, S., Lebedeva-Ivanova, N., Faleide, J.I., Morris, S., Morse, S., Castelltort, S., in review. Bjørnelva: A Pleistocene braided river discovered and characterized in high-resolution 3D seismic data in the SW Barents Sea. Journal of Geophysical Research: Earth Surface.

Bentley, M.J., Anderson, J.B., 1998. Glacial and marine geological evidence for the ice sheet configuration in the Weddell Sea-Antarctic Peninsula region during the Last Glacial Maximum. Antarctic Science 10, 309-325.

Bjarnadóttir, L.R., Winsborrow, M.C.M., Andreassen, K., 2014. Deglaciation of the central Barents Sea. Quaternary Science Reviews 92, 208-226.

Bradwell, T., Stoker, M.S., 2016. Recessional moraines in nearshore waters, northern Scotland. In: Dowdeswell, J.A., Canals, M., Jakobsson, M., Todd, B.J., Dowdeswell, E.K., Hogan, K. 
(Eds.), Atlas of submarine glacial landforms: Modern, Quaternary and Ancient. Geological Society, London, Memoirs 46, 63-64.

Burton, D.J., Dowdeswell, J.A., Hogan, K.A., Noormets, R., 2016. Little Ice Age terminal and retreat moraines in Kollerfjorden, NW Spitsbergen. In: Dowdeswell, J.A., Canals, M., Jakobsson, M., Todd, B.J., Dowdeswell, E.K., Hogan, K. (Eds.), Atlas of submarine glacial landforms: Modern, Quaternary and Ancient. Geological Society, London, Memoirs 46, 71-72.

Butt, F.A., Drange, H., Elverhøi, A., Otterå, O.H., Solheim, A., 2002. Modelling Late Cenozoic isostatic elevation changes in the Barents Sea and their implications for oceanic and climatic regimes: preliminary results. Quaternary Science Reviews 21, 1643-1660.

Bøe, R., Rise, L., Ottesen, D., 1998. Elongate depressions on the southern slope of the Norwegian Trench (Skagerrak): morphology and evolution. Marine Geology 146, 191-203.

Bøe, R., Ottesen, D., Rise, L., Dowdeswell, J.A., 2016. Streamlined ridges and depressions in the glacial sediments of the Arendal Terrace, Norwegian Skagerrak. In: Dowdeswell, J.A., Canals, M., Jakobsson, M., Todd, B.J., Dowdeswell, E.K., Hogan, K. (Eds.), Atlas of submarine glacial landforms: Modern, Quaternary and Ancient. Geological Society, London, Memoirs 46, $205-$ 206.

Clayton, L., Moran, S.R., 1974. A glacial process-form model. In: Coates, D.R. (Ed.), Glacial Geomorphology, State Univ. N.Y., Binghamton, Publ. Geomorphol., 89-119.

Cook, A.E., Goldberg, D., Kleinberg, R.L., 2008. Fracture controlled gas hydrate systems in the Gulf of Mexico. Marine and Petroleum Geology 25, 845-859.

Costard, F.M., Kargel, J.S., 1995. Outwash plains and thermokarst on Mars. Icarus 114, 93-112.

Dimakis, P., Braathen, B.I., Faleide, J.I., Elverhøi, A., Gudlaugsson, S.T., 1998. Cenozoic erosion and the preglacial uplift of the Svalbard-Barents Sea region. Tectonophysics 300, 311-327.

Dowdeswell, J.A., Ottesen, D., 2013. Buried iceberg ploughmarks in the early Quaternary sediments of the central North Sea: A two-million year record of glacial influence from 3D seismic data. Marine Geology 344, 1-9. 
Dowdeswell, J.A., Ottesen, D., 2016. Submarine landform assemblage for Svalbard surge-type tidewater glaciers. In: Dowdeswell, J.A., Canals, M., Jakobsson, M., Todd, B.J., Dowdeswell, E.K., Hogan, K. (Eds.), Atlas of submarine glacial landforms: Modern, Quaternary and Ancient. Geological Society, London, Memoirs 46, 151-154.

Dowdeswell, J.A., Ottesen, D., Evans, J., Ó Cofaigh, C., Anderson, J.B., 2008. Submarine glacial landforms and rates of ice-stream collapse. Geology 36, 819-822.

Dowdeswell, J.A., Solheim, A., Ottesen, D., 2016. Rhombohedral crevasse-fill ridges at the marine margin of a surging Svalbard ice cap. In: Dowdeswell, J.A., Canals, M., Jakobsson, M., Todd, B.J., Dowdeswell, E.K., Hogan, K. (Eds.), Atlas of submarine glacial landforms: Modern, Quaternary and Ancient. Geological Society, London, Memoirs 46, 73-74.

Dunlop, P., Clark, C.D., Hindmarsh, R.C.A., 2008. Bed ribbing instability explanation: Testing a numerical model of ribbed moraine formation arising from coupled flow of ice and subglacial sediment. Journal of Geophysical Research 113, F03005.

Ely, J.C., Clark, C.D., Spagnolo, M., Stokes, C.R., Greenwood, S.L., Hughes, A.L.C., Dunlop, P., Hess, D., 2016. Do subglacial bedforms comprise a size and shape continuum? Geomorphology 257, 108-119.

Faleide, T.S., Midtkandal, I., Planke, S., Corseri, R., Faleide, J.I., Nystuen, J.P., in review. Highresolution seismic imaging of an Early Cretaceous delta (and tectonic activity) in the southwestern Barents Sea. Journal of Norwegian Geology.

Farin, N.G.T., 1980. The use of regional geological surveys in the North Sea and adjacent areas in the recognition of offshore hazards. In: Ardus, D.A. (Ed.), Offshore Site Investigation. Graham and Trottman Publishers, London, 5-22.

French, H.M., Demitroff, M., Forman, S.L., Newell, W.L., 2007. A chronology of Late-Pleistocene permafrost events in southern New Jersey, Eastern USA. Permafrost and Periglacial Processes 18, 49-59. 
Gehrmann, A., Harding, C., 2018. Geomorphological Mapping and Spatial Analyses of an Upper Weichselian Glacitectonic Complex Based on LiDAR Data, Jasmund Peninsula (NE Rügen), Germany. Geosciences 8 (6), 208.

Gentoso, M.J., Evenson, E.B., Kodama, K.P., Iverson, N.R., Alley, R.B., Berti, C., Kozlowski, A., 2011. Exploring till bed kinematics using AMS magnetic fabrics and pebble fabrics: the Weedsport drumlin field, New York State, USA. Boreas 10.1111.

Grasby, S., Osadetz, K., Betcher, R., Render, F., 2000. Reversal of the regional-scale flow system of the Williston basin in response to Pleistocene glaciation. Geology 28, 635-638.

Grosse, G., Jones, B., Arp, C., 2013. Thermokarst lakes, drainage, and drained basins. In: Shroder, J., (Ed.), Treatise on Geomorphology. Academic Press, San Diego, CA, vol. 8, Glacial and Periglacial Geomorphology, 325-353.

Gudlaugsson, E., Humbert, A., Winsborrow, M., Andreassen, K., 2013. Subglacial roughness of the former Barents Sea ice sheet. Journal of Geophysical Research, Earth Surface, 118, 25462556.

Hättestrand, C., Kleman, J., 1999. Ribbed moraine formation. Quaternary Science Reviews 18, 43-61.

Hassol, 2004. Impacts of a warming Arctic. Cambridge University Press, 2004.

Hjelstuen, B.O., Eldholm, O., Faleide, J.I., 2007. Recurrent Pleistocene mega-failures on the SW Barents Sea margin. Earth and Planetary Science Letters 258, 605-618.

Hughes, A.L.C., Gyllencreutz, R., Lohne, Ø.L., Mangerud, J., Svendsen, J.I., 2016. The last Eurasian ice sheets - a chronological database and time-slice reconstruction, DATED-1. Boreas 45, $1-45$.

Huuse, M., Le Heron, D.P., Dixon, R., Redfern, J., Moscariello, A., Craig, J., 2012. Glaciogenic reservoirs and hydrocarbon systems: an introduction. In: Huuse, M., Redfern, J., Le Heron, R.J., Dixon, R.J., Moscariello, A., Craig, J., (Eds.), Geological Society of London Special Publications 368, 1-28. 
Jakobsson, M., Anderson, J.B., Nitsche, F.O., Dowdeswell, J.A., Gyllencreutz, Kirchner, N., Mohammad, R., O’Regan, M., Alley, R.B., Anandakrishnan, S., Eriksson, B., Kirshner, A., Fernandez, R., Stolldorf, T., Minzoni, R., Majewski, W., 2011. Geological record of ice shelf break-up and grounding line retreat, Pine Island Bay, West Antarctica. Geology 39, 691-694.

Jakobsson, M., Gyllencreutz, R., Mayer, L.A., Dowdeswell, J.A., Canals, M., Todd, B.J., Dowdeswell, E.K., Hogan, K.A., Larter, R.D., 2016. Mapping submarine glacial landforms using acoustic methods. In: Dowdeswell, J.A., Canals, M., Jakobsson, M., Todd, B.J., Dowdeswell, E.K., Hogan, K. (Eds.), Atlas of submarine glacial landforms: Modern, Quaternary and Ancient. Geological Society, London, Memoirs 46, 17-40.

Kallweit, R.S., Wood, L.C., 1982. The limits of resolution of zero-phase wavelets. Geophysics 47, 1351046.

King, L.H., MacLean, B., 1970. Pockmarks on the Scotian shelf. Geological Society of America Bulletin $81,3141-3148$.

King, E.L., Rise, L., Bellec, V.K., 2016. Crescentic submarine hills and holes produced by iceberg calving and rotation. In: Dowdeswell, J.A., Canals, M., Jakobsson, M., Todd, B.J., Dowdeswell, E.K., Hogan, K. (Eds.), Atlas of submarine glacial landforms: Modern, Quaternary and Ancient. Geological Society, London, Memoirs 46, 267-268.

Kleman, J., 1994. Preservation of landforms under ice sheets and ice caps. Geomorphology 9, 19-32.

Kleman, J., Borgström, I., 1996. Reconstruction of palaeo-ice sheets: the use of geomorphological data. Earth Surface Processes and Landforms 21, 893-909.

Kleman, J., Glasser, N.F., 2007. The subglacial thermal organization (STO) of ice sheets. Quaternary Science Reviews 26, 585-597.

Kleman, J., Hättestrand, C., 1999. Frozen-bed Fennoscandian and Laurentide ice sheets during the Last Glacial Maximum. Nature 402, 63-66.

Kokelj, S.V., Jorgenson, M.T., 2013. Advances in Thermokarst Research. Permafrost and periglacial processes 24, 108-119. 
Ktenas, D., Meisingset, I., Henriksen, E., Nielsen, J.K., in press. Estimation of net apparent erosion in the southwestern Barents Sea by applying velocity inversion analysis. Petroleum Geoscience.

Kvenvolden, 1988. Methane hydrate - A major reservoir of carbon in the shallow geosphere? Chemical Geology 71, 41-51.

Laberg, J.S., Vorren, T.O., 1995. Late Weichselian submarine debris flow deposits on the Bear Island Trough mouth fan. Marine Geology 127, 45-72.

Laberg, J.S., Andreassen, K., Vorren, T.O., 2012. Late Cenozoic erosion of the high-latitude southwestern Barents Sea shelf revisited. GSA Bulletin 124, 77-88.

Lambeck, K., Purcell, A., Zhao, J. \& Svensson, N.-O. (2010): The Scandinavian Ice Sheet: from MIS 4 to the end of the last Glacal Maximum. Boreas 39, 410 - 435.

Lobkovsky, L., Ananyev, R., Dmitrevskiy, N., Dudarev, O., Jakobsson, M., Nikiforov, S., Roslyakov, A., 2016. Permafrost patterns in the SE Laptev Sea, East Siberian Arctic Ocean. In: Dowdeswell, J.A., Canals, M., Jakobsson, M., Todd, B.J., Dowdeswell, E.K., Hogan, K. (Eds.), Atlas of submarine glacial landforms: Modern, Quaternary and Ancient. Geological Society, London, Memoirs 46, 311-312.

López-Martínez, J., Muñoz, A., Dowdeswell, J.A., Linés, C., Acosta, J., 2011. Relict sea-floor ploughmarks record deep-keeled Antarctic icebergs to $45^{\circ} \mathrm{S}$ on the Argentine margin. Marine Geology 288, 43-48.

Mackay, J.R., 1998. Pingo growth and collapse, Tuktoyaktuk Peninsula area, western Arctic coast, Canada: a long-term field study. Geogr. Phys. Quatern. 52(3), 271-323.

Maslin, M., Owen, M., Betts, R., Day, S., Jones, T.D., Ridgwell, A., 2010. Gas hydrates: past and future geohazard? Philosophical Transactions of the Royal Society A 368, 2369-2393.

Mazzini, A., Svensen, H.H., Forsberg, C.F., Linge, H., Lauritzen, S.E., Haflidason, H., Hammer, Ø., Planke, S., Tjelta, T.I., 2017. Earth and Planetary Science Letters 464, 24-34. 
Moran, S.R., Clayton, I., Hooke, R.LeB., Fenton, M.M., Andriashek, L.D., 1980. Glacier-bed landforms of the prairie region of North America. Journal of Glaciology 25, 457-476.

Morgenstern, A., Grosse, G., Günther, F., Fedorova, I., Schirrmeister, L., 2011. Spatial analyses of thermokarst lakes and basins in Yedoma landscapes of the Lena Delta. The Cryosphere 5, 849-867.

Morgenstern, A., Ulrich, M., Günther, F., Roessler, S., Fedorova, I.V., Rudaya, N.A., Wetterich, S., Boike, J., Schirmeister, L., 2013. Evolution of thermokarst in East Siberian ice-rich permafrost: A case study. Geomorphology 201, 363-379.

Murton, J.B., 2009. Global warming and thermokarst. Permafrost Soils, 185-209.

Nygård, A., Sejrup, H.P., Haflidason, H., Bryn, P., 2005. The glacial North Sea Fan, southern Norwegian Margin: architecture and evolution from the upper continental slope to the deep-sea basin. Marine and Petroleum Geology 22, 71-84.

Nygård, A., Sejrup, H.P., Haflidason, H., Lekens, W.A.H., Clark, C.D., Bigg, G.R., 2007. Extreme sediment and ice discharge from marine-based ice streams: New evidence from the North Sea. Geology 35, 395-398.

Ó Cofaigh, C., Dowdeswell, J.A., Allen, C.S., Hiemstra, J.F., Pudsey, C.J., Evans, J., Evans, D.J.A., 2005. Flow dynamics and till genesis associated with a marine-based Antarctic paleo-ice stream. Quaternary Science Reviews 24, 709-740.

Patton, H., Hubbard, A., Andreassen, K., Winsborrow, M., Stroeven, A.P., 2016. The build-up, and dynamical sensitivity of the Eurasian ice-sheet complex to Late Weichselian climatic and oceanic forcing. Quaternary Science Reviews 153, 97-121.

Patton, H., Hubbard, A., Andreassen, K., Auriac, A., Whitehouse, P.L., Stroeven, A.P., Shackleton, C., Winsborrow, M., Heyman, J., Hall, A.M., 2017. Deglaciation of the Eurasian ice sheet complex. Quaternary Science Reviews 169, 148 - 172. 
Piasecka, E.D., Winsborrow, M.C.M., Andreassen, K., Stokes, C.R., 2016. Reconstructing the retreat dynamics of the Bjørnøyrenna Ice Stream based on new 3D seismic data from the central Barents Sea. Quaternary Science Reviews 151, 212-227.

Pedersen, S.A.S., 2005. Structural analysis of the Rubjerg Knude Glaciotectonic Complex, Vendsyssel, northern Denmark. Geological Survey of Denmark and Greenland Bulletin 8, 192 pp.

Pedersen, S.H.S., 2012. Glaciodynamic sequence stratigraphy. Geological Society, London, Special Publications 368, SP368-2.

Pedersen, S.H.S., Boldreel, L.O., 2017. Seismic investigation of lake Esrum Sø, Denmark - glacial morphology or wrench fault tectonics. 79. Tagung der Arbeitsgemeindschaft Norddeutscher Geologen, Rendsburg, Hefte 1/2017, 2 pp.

Phillips, E., Everest, D., Diaz-Doce, D., 2010. Bedrock controls on subglacial landform distribution and geomorphological processes: Evidence from the Late Devensian Irish Sea Ice Stream. Sedimentary Geology 232, 98-118.

Polteau, S., Lebedeva-Ivanova, N., Bellwald, B., Planke, S., Zastrozhov, D., Vanneste, M., Sauvin, G., Myklebust, R., Buenz, S., Plaza-Faverola, A., Waage, M. and Berndt, C. [in press] Highresolution 3D site characterization. Near Surface Geoscience Conference and Exhibition 2018, Extended Abstracts 2018.

Posamentier, H.W., Davies, R.J., Cartwright, J.A., Wood, L., 2007. Seismic geomorphology - an overview. Geological Society, London, Special Publications 277, 1-14.

Rise, L., Olesen, O., Rokoengen, K., Ottesen, D., Riis, F., 2004. Mid-Pleistocene ice drainage pattern in the Norwegian Channel imaged by 3D seismic. Quaternary Science Reviews 23, 2323-2335.

Rise, L., Bellec, V.K., Ottesen, D., Bøe, R., Thorsnes, T., 2016. Hill-hole pairs on the Norwegian continental shelf. In: Dowdeswell, J.A., Canals, M., Jakobsson, M., Todd, B.J., Dowdeswell, E.K., Hogan, K. (Eds.), Atlas of submarine glacial landforms: Modern, Quaternary and Ancient. Geological Society, London, Memoirs 46, 203-204. 
Rüther, D.C., Mattingsdal, R., Andreassen, K., Forwick, M., Husum, K., 2011. Seismic architecture and sedimentology of a major grounding zone system deposited by the Bjørnøyrenna Ice Stream during Later Weichselian deglaciation. Quaternary Science Reviews 30, 2776-2792.

Rüther, D.C., Winsborrow, M., Andreassen, K., Forwick, M., 2017. Grounding line proximal sediment characteristics at a marine-based, late-stage ice stream margin. Journal of Quaternary Science $32,463-474$.

Salvigsen, O., 1981. Radiocarbon dated raised beaches in Kong Karls Land, Svalbard, and their consequences for the glacial history of the Barents Sea. Geografiska Annaler 63, 280-291.

Sannel, A.B.K., Kuhry, P., 2011. Warming-induced destabilization of peat plateau/thermokarst lake complexes. Journal of Geophysical Research: Biogeosciences 116, G3.

Schuur, E.A.G., Bockheim, J., Canadell, J.G., Euskirchen, E., Field, C.B., Goryachkin, S.V., Hagemann, S., Kuhry, P., Lafleur, P.M., Mazhitova, H.L.G., Nelson, F.E., Rinke, A., Romanovsky, V.E., Shiklomanov, N., Tarnocai, C., Venevsky, S., Vogel, J.G., Zimov, S.A., 2008. Vulnerability of Permafrost Carbon to Climate Change: Implications for the Global Carbon Cycle. BioScience 58, 701-714.

Serov, P., Vadakkepuliyambatta, S., Mienert, J., Patton, H., Portnov, A., Silyakova, A., Panieri, G., Carroll, M.L., Carroll, J.L., Andreassen, K., Hubbard, A., 2017. Postglacial response of Arctic Ocean gas hydrates to climatic amelioration. Proceedings of the National Academy of Science, 201619288.

Shaw, J., Piper, D.J.W., Fader, G.B.J., King, E.L., Todd, B.J., Bell, T., Batterson, M.J., Liverman, D.G.E., 2006. Quaternary Science Reviews 25, 2059-2081.

Sheriff, R.E., 1997. Encyclopedic Dictionary of Exploration Geophysics. Society of Exploration Geophysicists. Third edition. 386 pp.

Soare, R.J., Osinski, G.R., Roehm, C.L., 2008. Thermokarst lakes and ponds on Mars in the very recent (late Amazonian) past. Earth and Planetary Science Letters 272, 382-393. 
Solheim, A., Kristoffersen, Y., 1984. Sediment Distribution above the Upper Regional Unconformity and the Glacial History of Western Barents Sea. Norsk Polarinstitutt Skrifter. 189 (B).

Solheim, A., Elverhøi, A., 1985. A pockmark field in the Central Barents Sea; gas from a petrogenic source? Polar Research 3, 11-19.

Solheim, A., Pfirman, S.L., 1985. Sea-floor morphology outside a grounded, surging glacier; Bråsvellbreen, Svalbard. Marine Geology 65, 127-143.

Solheim, A., Andersen, E.S., Elverhøi, A., Fiedler, A., 1996. Late Cenozoic depositional history of the western Svalbard continental shelf, controlled by subsidence and climate. Global and Planetary Change 12, 135-148.

Spagnolo, M., Clark, C.D., Ely, J.E., Stokes, C.R., Anderson, J.B., Andreassen, K., Graham, A.G.C., King, E.C., 2014. Size, shape and spatial arrangement of mega-scale glacial lineations from a large and diverse dataset. Earth Surface Processes and Landforms 39, 1432-1448.

Stokes, C.R., Clark, C.D., 2002. Are long subglacial bedforms indicative of fast ice flow? Boreas 31, 239-249.

Stokes, C.R., Clark, C., Lian, O., Tulaczyk, S., 2007. Ice stream sticky spots: A review of their identification and influence beneath contemporary and palaeo-ice streams. Earth Science Reviews 81, 217-249.

Stokes, C.R., Spagnolo, M., Clark, C.D., O’Cofaigh, C., Lian, O.B., Dunstone, R.B., 2013. Formation of mega-scale glacial lineations on the Dubawnt Lake Ice Stream bed: 1. Size, shape and spacing from a large remote sensing dataset. Quaternary Science Reviews 77, 190-209.

Stroeven AP, Hättestrand C, Kleman J, Heyman J, Fabel D, Fredin O, Goodfellow BW, Harbor JM, Jansen JD, Olsen L, Caffee MW, Fink D, Lundqvist J, Rosqvist GC, Strömberg B, Jansson KN (2015) Deglaciation of Fennoscandia. Quaternary Science Reviews 147, 91 -121.

Sættem, J., Poole, D.A.R., Ellingsen, L., Sejrup, H.P., 1992. Glacial geology of outer Bjørnøyrenna, southwestern Barents Sea. Marine Geology 103, 15-51. 
Tasianas, A., Bünz, S., Bellwald, B., Hammer, Ø., Planke, S., Lebedeva-Ivanova, N., Krassakis, P., 2018. High-resolution 3D seismic study of pockmarks and shallow fluid flow systems at the Snøhvit hydrocarbon field in the SW Barents Sea. Marine Geology 403, 247-261.

Tishchenko, P., Hensen, C., Wallmann, K., Wong, C.S., 2005. Calculation of the stability and solubility of methane hydrate in seawater. Chemical Geology 219, 37-52.

Tulaczyk, S., Scherer, R., Clark, CD., 2001. A ploughing model for the origin of weak tills beneath ice streams: a qualitative statement. Quaternary International 86, 59-70.

Vorren, T.O., Laberg, J.S., 1997. Trough mouth fans - paleoclimate and ice-sheet monitors. Quaternary Science Reviews 16, 865-881.

Vorren, T.O., Kristoffersen, Y., Andreassen, K., 1986. Geology of the inner shelf west of North Cape, Norway. Norsk Geologisk Tidsskrift 66, 99-105.

Wadham, J.L., Arndt, S., Tulaczyk, S., Stibal, M., Tranter, M., Telling, J., Lis, G.P., Lawson, E., Ridgwell, A., Dubnick, A., Sharp, M.J., Anesio, A.M., Butler, C.E.H., 2012. Potential methane reservoirs beneath Antarctica. Nature 488, 633-637.

Wallmann, K., Pinero, E., Burwicz, E., Haeckel, M., Hensen, C., Dale, A., Ruepke, L., 2012. The global inventory of methane hydrate in marine sediments: a theoretical approach. Energies 5, 24492498.

Walter, K.M., Edwards, M.E., Grosse, G., Zimov, S.A., Chapin III, F.S., 2007. Thermokarst Lakes as a Source of Atmospheric CH4 during the Last Deglaciation. Science 318, 633-636.

Weinberger, J.L., Brown, K.M., 2006. Fracture networks and hydrate distribution at Hydrate Ridge, Oregon. Earth and Planetary Science Letters 245, 123-136.

Winsborrow, M.C.M., Clark, C.D., Stokes, C.R., 2010. What controls the location of ice streams? Earth Science Reviews 103, 45-59. 
1021 Winsborrow, M.C.M., Andreassen, K., Hubbard, A., Plaza-Faverola, A., Gudlaugsson, E., Patton, H., 2016. Regulation of ice stream flow through subglacial formation of gas hydrates. Nature Geoscience 9, 370-374.

1024

1025

1026

1027

1028

Zimov, S.A., Voropaev, Y.V., Semiletov, I.P., Davidov, S.P., Prosiannikov, S.F., Chapin III, F.S., Chapin, M.C., Trumbore, S., Tyler, S., 1997. North Siberian Lakes: A Methane Source Fueled by Pleistocene Carbon. Science 277, 800-802.

www.npd.no, Norwegian Petroleum Directorate (NPD), Stavanger, Norway, 30.09.2016. Factpages of exploration wellbores. [online]. http://factpages.npd.no/factpages/ 